\title{
A Match-based approach to the estimation of polar stratospheric ozone loss using Aura Microwave Limb Sounder observations
}

\author{
N. J. Livesey ${ }^{1}$, M. L. Santee ${ }^{1}$, and G. L. Manney ${ }^{2,3}$ \\ ${ }^{1}$ Jet Propulsion Laboratory, California Institute of Technology, Pasadena, California, USA \\ ${ }^{2}$ NorthWest Research Associates, Socorro, NM, USA \\ ${ }^{3}$ New Mexico Institute of Mining and Technology, Socorro, NM, USA \\ Correspondence to: N. J. Livesey (nathaniel.j.livesey@jpl.nasa.gov)
}

Received: 19 February 2015 - Published in Atmos. Chem. Phys. Discuss.: 2 April 2015

Revised: 16 August 2015 - Accepted: 17 August 2015 - Published: 4 September 2015

\begin{abstract}
The well-established "Match" approach to quantifying chemical destruction of ozone in the polar lower stratosphere is applied to ozone observations from the Microwave Limb Sounder (MLS) on NASA's Aura spacecraft. Quantification of ozone loss requires distinguishing transport- and chemically induced changes in ozone abundance. This is accomplished in the Match approach by examining cases where trajectories indicate that the same air mass has been observed on multiple occasions. The method was pioneered using ozonesonde observations, for which hundreds of matched ozone observations per winter are typically available. The dense coverage of the MLS measurements, particularly at polar latitudes, allows matches to be made to thousands of observations each day. This study is enabled by recently developed MLS Lagrangian trajectory diagnostic (LTD) support products. Sensitivity studies indicate that the largest influence on the ozone loss estimates are the value of potential vorticity (PV) used to define the edge of the polar vortex (within which matched observations must lie) and the degree to which the PV of an air mass is allowed to vary between matched observations. Applying Match calculations to MLS observations of nitrous oxide, a long-lived tracer whose expected rate of change is negligible on the weekly to monthly timescales considered here, enables quantification of the impact of transport errors on the Match-based ozone loss estimates. Our loss estimates are generally in agreement with previous estimates for selected Arctic winters, though indicating smaller losses than many other studies. Arctic ozone losses are greatest during the 2010/11 winter, as seen in prior studies, with $2.0 \mathrm{ppmv}$ (parts per million by volume) loss estimated at $450 \mathrm{~K}$ potential temperature $(\sim 18 \mathrm{~km}$ altitude).
\end{abstract}

As expected, Antarctic winter ozone losses are consistently greater than those for the Arctic, with less interannual variability (e.g., ranging between 2.3 and $3.0 \mathrm{ppmv}$ at $450 \mathrm{~K}$ ). This study exemplifies the insights into atmospheric processes that can be obtained by applying the Match methodology to a densely sampled observation record such as that from Aura MLS.

\section{Introduction}

The chemical, microphysical, dynamical and radiative processes that give rise to the Antarctic ozone hole each year (Farman et al., 1985; Solomon, 1999; World Meteorological Organization, 2014) also occur in the Arctic, though with less severity and large interannual variability (e.g., Manney et al., 2003; Santee et al., 2003; Kuttippurath et al., 2010; Manney et al., 2011). This marked hemispheric disparity originates from the greater zonal asymmetry in high northern latitude topography compared to that in the south, leading to reductions in the size and longevity of the Arctic winter polar vortex and increasing its permeability (e.g., Andrews, 1989; Schoeberl et al., 1992; Manney et al., 1994). In both hemispheres, air trapped within these vortices is subject to descent through radiative cooling during polar night, with the lower stratosphere eventually cooling to temperatures at which polar stratospheric clouds (PSCs) form from gaseous nitric acid, sulfate aerosols, and water vapor (McCormick et al., 1982; Toon et al., 1986, 1990; Crutzen and Arnold, 1986). Chemical reactions on the surfaces of and within these cloud particles liberate atmospheric chlorine species from 
reservoir forms $\left(\mathrm{HCl}\right.$ and $\left.\mathrm{ClONO}_{2}\right)$, priming the vortex region for chemical ozone destruction, which occurs once sunlight returns and converts the chlorine into ozone-depleting forms (Solomon et al., 1986; Molina and Molina, 1987; Anderson et al., 1989).

In addition to chemical reactions, various dynamical processes affect wintertime stratospheric ozone abundances, including descent within the polar vortex, mixing of lower latitude air into the vortex, and mixing within the vortex itself. These other influences on the ozone distribution present a challenge to the accurate quantification of chemical ozone destruction, particularly in the more dynamically active Arctic vortex, and several approaches have been employed to distinguish the chemical and dynamical contributions to changes in ozone abundance each winter (Harris et al., 2002; World Meteorological Organization, 2007).

Many approaches to ozone loss quantification compute the difference between observed ozone and a model estimate of "passive ozone", the latter being a chemically inert tracer subject to the same dynamical processes as "real" ozone. This method was first developed by Manney et al. (1995b, a) to quantify ozone loss during the 1992/93 Arctic winter, using a trajectory-based passive ozone estimate, and has been subsequently applied in similar form to other seasons (e.g., Manney et al., 1996a, b, 1997, 2003; Schoeberl et al., 2002). Where a full chemistry transport model is employed (e.g., Deniel et al., 1998; Goutail et al., 1999; Singleton et al., 2005, 2007; L. Feng et al., 2007; Grooß and Müller, 2007; Rösevall et al., 2008; Jackson and Orsolini, 2008; Kuttippurath et al., 2010, 2012; Feng et al., 2011; Brakebusch et al., 2013), ozone loss can be estimated by comparing the modeled passive ozone to both the ozone simulated by the same model and to observed ozone, with comparisons between the latter two fields typically used to quantify the overall accuracy of the model calculations (both from the dynamical and chemical perspective). The passive subtraction approach can be taken a stage further by considering a "pseudo passive" ozone tracer (Singleton et al., 2005), subject to both dynamical and gas-phase chemistry influences, but not the losses due to chlorine activated through heterogeneous processes. "Tracer correlation" methods also effectively derive passive ozone estimates, through consideration of relationships between ozone and a chemically inert trace gas such as nitrous oxide ( $\mathrm{N}_{2} \mathrm{O}$; e.g., Proffitt et al., 1993; Michelsen et al., 1998). However, mixing processes distort these relationships (e.g., Waugh et al., 1997; Michelsen et al., 1998; Plumb et al., 2000; Müller et al., 2005; Plumb, 2007), limiting the accuracy of resulting ozone loss estimates; consideration of multiple tracers can enable more robust estimates (e.g., Esler and Waugh, 2002; Jin et al., 2006). Similarly, the "vortex average descent" approach (e.g., Hoppel et al., 2002; Manney et al., 2006; Jin et al., 2006) estimates a passive ozone subject only to the descent that often dominates the dynamical effects on ozone within the vortex, neglecting transport into and out of the vortex. The descent may be calculated using diabatic heating rates, or the vortex-averaged changes in a long-lived tracer such as $\mathrm{N}_{2} \mathrm{O}$.

An alternative, though not unrelated, approach to passive subtraction is the "Match" technique pioneered by von der Gathen et al. (1995), whereby changes in ozone between two or more observations of the same air mass provide a measure of chemical ozone loss. Trajectory calculations are used to estimate the air mass motions and identify the "matched" measurements. For Match approaches based on ozonesondes and other in situ observations, measurement times and/or locations are often specifically targeted to sample previously observed air masses. The technique has been refined, characterized, and applied to the quantification of ozone loss in many Arctic winters (e.g., Rex et al., 1997, 1998, 1999; Harris et al., 2002; Lehmann et al., 2005) and in the Antarctic (e.g., Frieler et al., 2006; Schofield et al., 2015). The approach has also been applied to observations from spaceborne solar occultation sounders (e.g., Sasano et al., 2000; Terao et al., 2002, 2012; Hoppel et al., 2005). Similar techniques have been used in a variety of other studies, including quantification of chemical kinetics constants from observations in the polar vortex (von Hobe et al., 2007; Schofield et al., 2008; Sumińska-Ebersoldt et al., 2012); studies of PSC formation, chlorine activation and denitrification (e.g., Danilin et al., 2000; Santee et al., 2002; Rivière et al., 2003); dehydration processes occurring in the tropical tropopause layer (Inai et al., 2013); long-range transport of tropospheric pollutants (e.g., Methven et al., 2006); and validation of satellite observations (e.g., Morris et al., 2002; Danilin et al., 2002).

Section 2 of this paper reviews the Microwave Limb Sounder (MLS) instrument and the MLS $\mathrm{O}_{3}$ and $\mathrm{N}_{2} \mathrm{O}$ measurements used in this study, introduces the MLS Lagrangian trajectory diagnostics (LTDs), and describes the use of these to identify matched MLS observations. Section 3 describes the method by which ozone loss is estimated from matched observations, and quantifies the various uncertainties in these estimates. Section 4 compares our calculated ozone losses for the 2004/05 Arctic winter to those reported in past studies of that period, during which a notably large degree of ozone destruction occurred. Section 5 reviews the results for all the Arctic winters observed by MLS from 2004/05 to 2012/13, and the Antarctic winters from 2005 to 2012. Finally, Sect. 6 presents a summary of the study and outlines plans for further applications of this approach. The Appendix gives more information on the MLS Lagrangian trajectory diagnostics.

\section{MLS observations and match identification}

\subsection{The Aura Microwave Limb Sounder (MLS)}

The Microwave Limb Sounder (MLS) instrument (Waters et al., 2006) on the Aura spacecraft, launched in July 2004, measures vertical profiles of atmospheric composition, tem- 
perature, and cloud properties by vertically scanning the Earth's limb and observing atmospheric thermal microwave emissions. Aura MLS views the portion of the atmosphere directly in front of the spacecraft, performing a vertical scan of the limb tangent point from the surface to $\sim 90 \mathrm{~km}$ every $\sim 24.7 \mathrm{~s}$. The MLS data products used in this study, taken from the version 3 data set (Livesey et al., 2013), are vertical profiles of $\mathrm{O}_{3}$ and $\mathrm{N}_{2} \mathrm{O}$, deduced from observations in the 240 and $640 \mathrm{GHz}$ spectral regions, respectively.

Validation studies for the earlier version $2 \mathrm{MLS} \mathrm{O}_{3}$ product (Froidevaux et al., 2008; Jiang et al., 2007; Livesey et al., 2008) show that it agrees with other ozone observations to within $5-10 \%$ in the stratosphere. Differences between the version 2 and version 3 ozone products are negligible in the region considered here. The $\mathrm{O}_{3}$ vertical resolution (as estimated by the full width at half maximum of the averaging kernels, e.g., Livesey et al., 2006) is $2.5 \mathrm{~km}$ from 100 to $22 \mathrm{hPa}$, broadening to $3 \mathrm{~km}$ in both the lowermost and upper stratosphere. The MLS version 3 ozone measurements are scientifically useful between 261 and $0.02 \mathrm{hPa}$. Noise on the MLS radiances results in an estimated precision ranging from $0.02 \mathrm{ppmv}$ (parts per million by volume) in the lowermost stratosphere to $0.2 \mathrm{ppmv}$ at $1 \mathrm{hPa}$. A detailed quantification of the likely systematic errors, which was obtained by modeling the impact of individual error sources (e.g., calibration and spectroscopic uncertainty) on the MLS ozone profiles, indicates that an accuracy of 5-10\% can be expected in the lower stratosphere, consistent with the agreement seen with correlative data sets.

The MLS version $2 \mathrm{~N}_{2} \mathrm{O}$ product agrees with other stratospheric observations to within 5-10\% (Lambert et al., 2007), indicating that the bottom up $\mathrm{N}_{2} \mathrm{O}$ accuracy estimate of 10$25 \%$ may be pessimistic. Again, differences with version 3, used here (taken from observations at $640 \mathrm{GHz}$ during the years in this study), are negligible. The vertical resolution of the $\mathrm{N}_{2} \mathrm{O}$ product is $\sim 5 \mathrm{~km}$ throughout the stratosphere (poorer than that for $\mathrm{O}_{3}$ ), and the data are useful from 100 to $0.46 \mathrm{hPa}$. Precision on individual $\mathrm{N}_{2} \mathrm{O}$ measurements is estimated to be $15-20 \%$ in the vertical range considered here.

\subsection{Trajectory computation and MLS LTD products}

The MLS Lagrangian trajectory diagnostics (LTDs), upon which our analysis is based, are a set of 15 day forward and reverse trajectories launched from a curtain of points along the MLS observation track. The MLS LTDs are launched from the locations and times (to the nearest $20 \mathrm{~min}$ ) of each MLS profile, with parcels initialized at the MLS output pressure levels from 464 to $0.1 \mathrm{hPa}$, spaced at 12 levels per decade change in pressure for pressures of $1 \mathrm{hPa}$ and greater, and 6 levels in the decade between 1 and $0.1 \mathrm{hPa}$. In addition to these locations, a second, "flanking" set of launches is placed $20 \mathrm{~km}$ away (specifically, to the "right" of the MLS viewing track, i.e., eastward on the ascending side of the orbit, westward on the descending). These are used to diag- nose cases where significant wind shear and/or divergence may have affected match identification or other calculations. Although the trajectories are launched on pressure surfaces, they are advected using potential temperature as the vertical coordinate, with wind fields and diabatic heating rates taken from the GEOS-5.2 analysis data set (Rienecker et al., 2008). The earlier GEOS-5.1 analysis fields are used for observations prior to 13 August 2008 (differences in lower and middle stratospheric winds between these two versions are generally insignificant). The advection calculations are based on those used by Manney et al. (1994), customized for the LTD application, having a fourth-order Runge-Kutta integration with a 5 min time step.

Trajectory locations are saved every $20 \mathrm{~min}$ (four RungeKutta integrations). In addition to the trajectory latitude, longitude, and potential temperature, the temperature at the trajectory location is recorded, along with scaled potential vorticity (sPV, with scaling according to Dunkerton and Delisi, 1986, and Manney et al., 1994), and equivalent latitude (the latitude enclosing the same area as a given contour of SPV; Butchart and Remsberg, 1986), all taken from the GEOS5 analysis fields. To reduce the file volumes, all fields are stored as scaled two-byte integers (scaled $\log _{10}[\theta / \mathrm{K}]$ is used for potential temperature), leading to truncation errors equivalent to $\sim 500 \mathrm{~m}$ in the horizontal and $\sim 1.5 \mathrm{~m}$ in the vertical.

\subsection{Identifying matches}

The LTD information is used to identify cases where an air mass observed by MLS was subsequently observed again on a later orbit. The differences in observed ozone (or other species) can then be used to estimate chemical loss (or production). The dense MLS spatial coverage enables match criteria to be far stricter than those used for ozonesonde and solar occultation-based studies, where $500 \mathrm{~km}$ match radii are typical (e.g., Rex et al., 1998). For this study, matches are defined as cases where an MLS profile measured during a 20 min LTD output timestep lies within $100 \mathrm{~km}$ of the location of a trajectory launched from an earlier MLS observation. The impact of this choice of match radius on inferred ozone loss rates is discussed in Sect. 3.2. Even with this comparatively tight criterion, the density of MLS observations enables thousands of matches per day compared to the hundreds obtained each season in ozonesonde-based Match studies.

For each identified match, in addition to recording the origin and destination locations and times, and the "match distance" between the destination observation and the air parcel, several other parameters relating to the history of the air parcel between the observations are recorded. These include the maximum separation between the central and flanking trajectories and the range of sPV values experienced by the central trajectory. The amount of time the central air mass encountered solar zenith angles (SZAs) smaller than one degree less than the local (altitude-dependent) horizon angle 
(classified here as "daylight") is also recorded, as is the time spent with SZA one degree or more larger than the horizon angle ("darkness"), and the time with SZA between these limits ("twilight"). For simplicity, the trajectory altitudes in those calculations are estimated from their potential temperatures using the approximation given by Knox (1998), errors in which equate to $<\sim 0.3^{\circ} \mathrm{SZA}$ for typical polar winter temperatures.

\section{Polar ozone loss estimation}

\subsection{Computing loss from matched observations}

The estimation of polar vortex ozone loss from matched observations follows the methods established for ozonesondebased Match studies (e.g., Rex et al., 1998; Lehmann et al., 2005), with tighter criteria than they typically used, again enabled by the dense MLS spatial coverage. Specifically, matched observations are only included in ozone loss estimates if all of the following conditions are met:

1. both the origin and destination observations are within the polar vortex (defined as the region where the magnitude of sPV is greater than $1.4 \times 10^{-4} \mathrm{~s}^{-1}$, as discussed by Manney et al., 2007);

2. the range of sPV variability along the central trajectory is less than $25 \%$ of the mean sPV value (ozonesondebased Match studies typically use $40 \%$; e.g., Rex et al., 1998);

3. the flanking and central trajectories remain within $100 \mathrm{~km}$ of each other in the time between the origin and destination observations.

The scaling of potential vorticity enables the same value to be used as a vortex edge criterion throughout the vertical range. An additional advantage of sPV-based rather than equivalent latitude-based vortex edge definitions is that the same value is a good measure of the vortex edges in both hemispheres and throughout most of their lifecycles. Sensitivity of our results to all these criteria is quantified in Sect. 3.2 while Sect. 5 includes discussion of loss estimates using an equivalent latitude-based vortex edge criterion.

The MLS-observed ozone at the start and end of each match is computed by linearly interpolating the corresponding MLS profiles (in log pressure, as is dictated by the definition of the MLS state vector; Livesey et al., 2006) to the height of the trajectory (though we note that, in the case of the starting profile, such interpolation is not actually needed, as the trajectories are launched at the MLS output pressures). Ozone loss over a given time period and altitude range is then estimated by computing the change in ozone between each matched pair of observations within that period/range, considering each such difference to be a measurement of ozone loss vs. sunlight exposure time (time in either "daylight" or

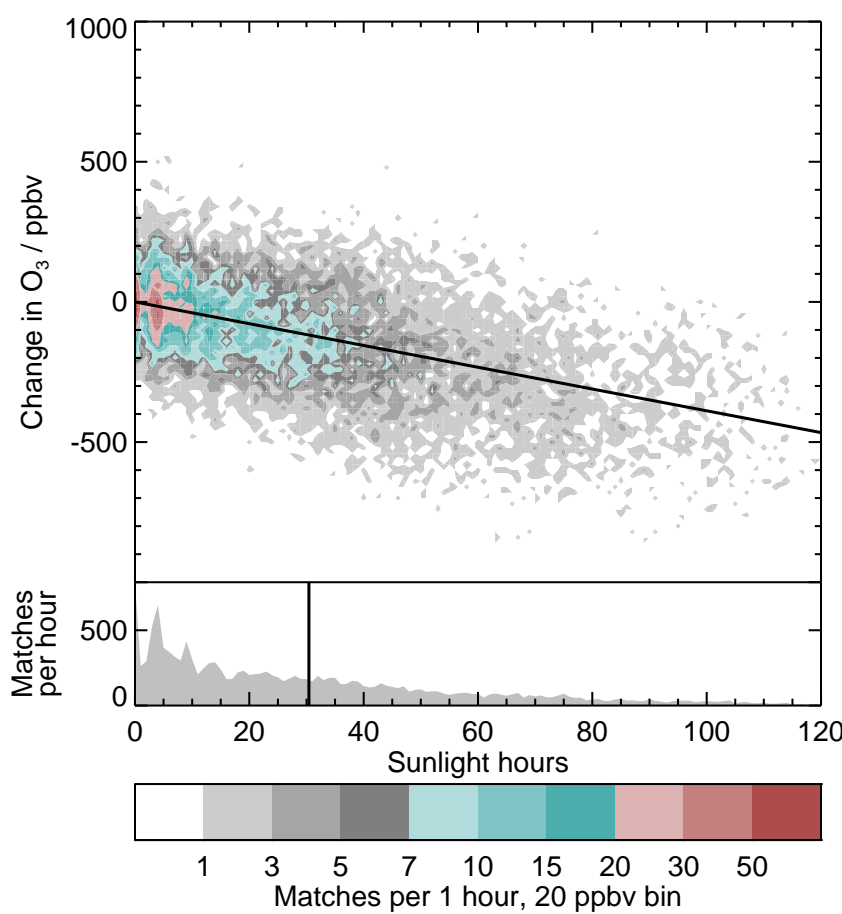

Figure 1. Two-dimensional histogram of change in $\mathrm{O}_{3}$ abundance vs. elapsed time in sunlight for $\sim 15000$ matched MLS observations in a $25 \mathrm{~K}$-thick window centered at $450 \mathrm{~K}$ potential temperature $(\sim 70 \mathrm{hPa}, \sim 18 \mathrm{~km})$ between 15 February and 1 March 2005. White indicates no values in a given bin; grays, cyans and reds indicate increasingly large populations. The sloping black line shows the fitted loss rate estimate of 3.9 ppbv per sunlight hour. The lower panel shows a histogram of the sunlight exposure times for the air masses between the matched observations, with a black vertical line denoting the mean of $\sim 30 \mathrm{~h}$.

"twilight" as described above), and fitting a straight line, constrained to pass through the origin (i.e., guaranteeing zero estimated loss for zero hours of exposure to sunlight), to these ozone change vs. exposure time data points. The slope of that line gives the inferred ozone loss rate. Figure 1 shows an example of such a fit for 15 February to 1 March 2005, a period of strong ozone loss during a well-studied Arctic winter, chosen as being representative of many other periods and altitudes quantified here.

In estimating the precision of the ozone loss results, consideration should be given to the error covariances between pairs of matched ozone measurements that involve the same observations (i.e., matches that have a shared origin, a shared destination, or cases where the origin of one match is the destination of another). Lehmann et al. (2005) describe a framework for properly accounting for these factors for ozonesonde- and occultation-based Match studies, and show that "classical" error quantifications (those that only account for scatter about the fit line, ignoring covariance) incorrectly quantify the precision of the ozone loss estimate. We apply the same method here, and find that the classical approach 
generally underestimates precision uncertainty by $30-50 \%$ at most altitudes. However, the comparatively large number of matched MLS observations leads to all such precision estimates being negligible compared to the other sources of uncertainty discussed in subsequent subsections. Accordingly, other than in Fig. 2, below, we neglect uncertainties related to the precision of the MLS measurements and the Match calculation.

\subsection{Sensitivity studies}

Figure 2 shows the same 15 February to 1 March 2005, $\sim 450 \mathrm{~K}$ ozone loss estimate obtained using the match criteria described above (magenta squares), along with other estimates generated by tightening and loosening each criterion independently (annotated colored circles and lines).

Changing the extent to which the flank and central trajectories are allowed to diverge (dark red points/line) has no significant impact on inferred ozone loss, even when no limit is applied (labeled "Unlim" in Fig. 2). However, as would be expected, tighter criteria do result in fewer matches being considered (Fig. 2a), and the remaining matches having a shorter mean "duration" (defined hereinafter as the elapsed time between the two matched observations, Fig. 2b). The match distance criterion (the distance between the air mass and the destination observation at the observation time, green points/line) similarly has little impact on ozone loss rate. In this case, while tighter criteria understandably give fewer valid matches, there is no significant impact on the mean duration of the matches that remain.

The choice of sPV value to use as the vortex edge criterion, within which both the origin and destination MLS observations must lie, does have a significant impact on the inferred amount of ozone loss (dark blue points/line), as previously noted by Grooß et al. (2008). Requiring the measurements to be deeper within the vortex tends to result in a larger ozone loss rate, consistent with the findings of Manney et al. (2006) and others for this period, when ozone loss was strongest in the center of the vortex and weaker towards the edge. Similar behavior is commonly, but not universally, seen in other years. Figure $2 \mathrm{c}$ shows that this criterion impacts the mean equivalent latitude of all the tracked air parcels, as would be expected.

Restricting the matches to those with less variability in sPV along the trajectory also increases estimated ozone loss (orange points/line) for all but the most stringent criterion of $2 \%$ variability (leftmost orange point in Fig. 2a). Tighter criteria not only reduce the number of matches and the mean match duration, they seemingly also favor matches located more deeply within the vortex (Fig. 2c). To check whether it is simply the mean match duration that is the underlying driver of this sensitivity (i.e., whether having less elapsed time between matched observation pairs inherently leads to larger estimates of ozone loss rate, regardless of the amount of sPV variability), an additional set of perturbations was per- formed where the match ensemble was randomly downsampled in a manner favoring retention of matches with durations shorter than a given threshold (pale-blue-colored points and line). This random thinning, while reducing the number of matches and the mean match duration as intended, has little impact on the estimated loss until the number of matches is reduced by around $40 \%$ (similar behavior is seen in the flank divergence case, as well as when we instead eliminate air masses exposed to the sun for more than a given amount of time between the observations, not shown). The sPV criterion, by contrast, impacts ozone loss estimates when as few as $\sim 15 \%$ of the trajectories are eliminated. Accordingly, it would appear that the atmospheric processes that give rise to variability in sPV along a trajectory (e.g., sub-grid scale mixing and diabatic descent), perhaps unsurprisingly, tend to reduce estimated ozone loss for a given air mass.

Applying this same analysis to other altitudes, and time periods (not shown), including over the Antarctic, consistently shows the vortex edge and SPV divergence criteria to have the strongest impact on estimated ozone loss (with the random thinning in many cases having a more benign signature than is seen in Fig. 2). Given that the vortex edge criterion essentially equates to the choice of the meteorological region within which one wishes to estimate loss, we will use the $1.4 \times 10^{-4} \mathrm{~s}^{-1}$ threshold here, except where specified otherwise. However, we note that, at higher altitudes (above $24 \mathrm{~km}$, potential temperatures larger than $\sim 600 \mathrm{~K}$ ), a larger cutoff value gives a better match to the vortex edge (Manney et al., 2015). In light of the clear impact of the SPV divergence criterion on the estimated loss rate, our final analyses will consider both the "standard" $25 \%$ criterion and a loss estimated using a $10 \%$ limit, referred to as the "tighter" estimate hereinafter.

\subsection{Estimating integrated ozone losses for each winter/spring}

Our ultimate objective is to quantify the total amount of chemical ozone loss as a function of altitude in each Arctic and Antarctic winter. Given that ozone loss rates vary significantly within each period, simply extending the approach described above, which estimates a constant loss rate, to a single season-long window would be inappropriate. To give a better estimate of cumulative ozone losses for a season we instead extend our approach to periods longer than our 15 day trajectory duration cutoff by performing the Match calculations described above in a moving 15 day window.

Figure 3 shows the results of these calculations for 1 January through 1 April 2005, one of the most intensively studied periods of Arctic ozone loss to date. This winter was atypically cold (Manney et al., 2006), with widespread PSC activity after mid-December 2004 (Santee et al., 2008). The dynamical behavior was complex, with significant mixing between the vortex edge and vortex core regions in the lower stratosphere from late January through February 

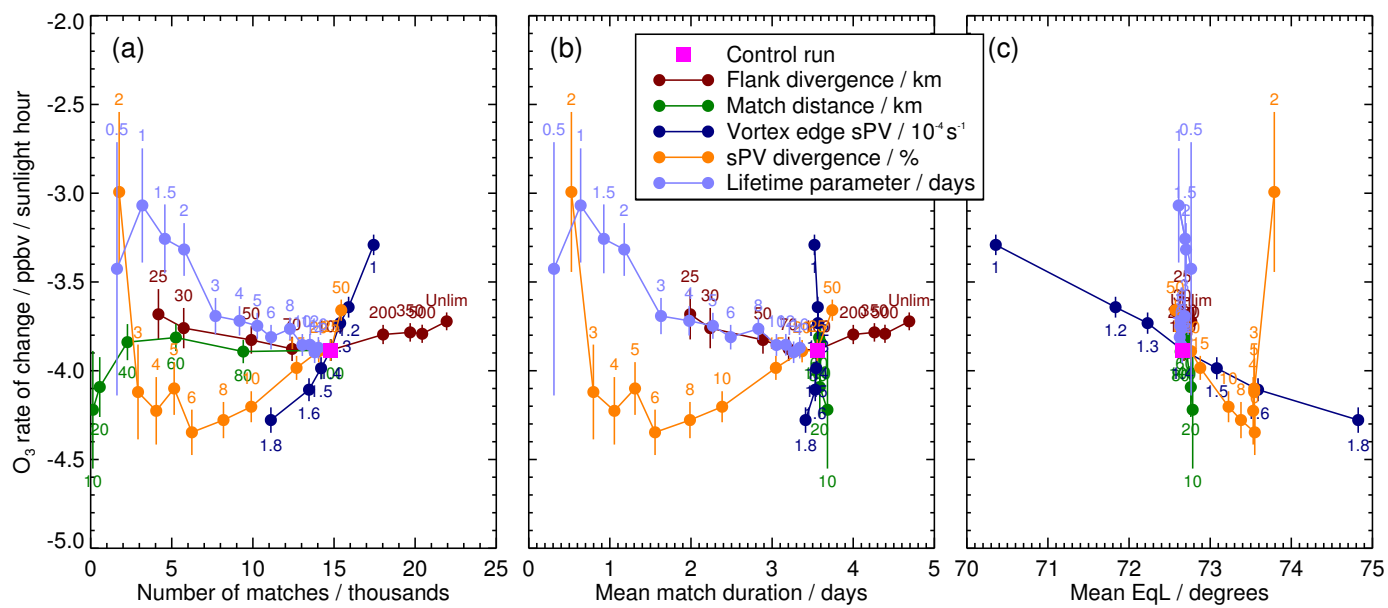

Figure 2. Arctic vortex-average ozone loss, estimated for the same altitude/day range as in Fig. 1, using the criteria given in the text (magenta square symbols), and estimated using various perturbed criteria (colored circles and lines, with colors defined in the legend). The three panels show the inferred ozone loss vs. (a) number of matches, (b) mean match duration, and (c) mean sPV for all the points along the match trajectories. Annotations above or below each colored point give the corresponding value of the perturbed criterion (units are given in the legend, "Unlim" indicates the case with the flank divergence criterion ignored). Error bars show the precision estimated by the Lehmann et al. (2005) approach (see text).

(Manney et al., 2006). Observations of ClO from MLS show that chlorine was deactivated after a 15 March "major final warming" (Manney et al., 2006; Santee et al., 2008). Figure $3 \mathrm{a}$ shows that the area of the polar vortex in the lower stratosphere was largely unchanged between late January and early March, after which it rapidly diminished following the mid-March warming. The vortex remained in near darkness until around 25 January (Fig. 3b), at which point average illumination steadily increased, reaching $12 \mathrm{~h}$ per day around 8 March. The greatest density of matches was in the mid- and lower stratosphere (Fig. 3c), with fewer below $400 \mathrm{~K}(\sim 16 \mathrm{~km})$, and a general decrease in the number of matches starting in late February, reflecting decreases in the area of the vortex within which matched observations must lie. Chemical ozone loss commenced around 12 January (Fig. 3d), consistent with findings from previous studies (e.g., Manney et al., 2006; Brakebusch et al., 2013), and hourly loss rates peaked around 30 January at $500 \mathrm{~K}$ $(\sim 20 \mathrm{~km})$ and 20 February at $450 \mathrm{~K}(\sim 18 \mathrm{~km})$. When scaled by the hours of sunlight available, the $450 \mathrm{~K}$ losses in late February are more significant than those at $500 \mathrm{~K}$ in the late January period (Fig. 3e). Integrating these losses from 1 January to 1 April (Fig. 3f) on constant potential temperature surfaces gives peak loss of slightly larger than $1 \mathrm{ppmv}$ at $450 \mathrm{~K}$. In addition, there are indications of a secondary peak of $\sim 0.8$ ppmv loss between 550 and $600 \mathrm{~K}$. Previous studies of the 2004/05 winter have shown that ozone loss at these altitudes largely resulted from nitrogen-based catalytic cycles, although the studies report different magnitudes and vertical distributions for the overall loss. Grooß and Müller (2007) find as much as $1.6 \mathrm{ppmv}$ loss at $600 \mathrm{~K}$, while Kuttippurath et al. (2010) find $\sim 1.2 \mathrm{ppmv}$ loss at the same altitude, and
Jackson and Orsolini (2008) report only $\sim 0.4$ ppmv loss. Section 4 discusses in more detail how our results compare with estimates from previous studies.

\subsection{Use of nitrous oxide to quantify ozone loss accuracy}

The accuracy of MLS Match-based ozone loss estimates is further quantified by applying the same calculations to the MLS observations of $\mathrm{N}_{2} \mathrm{O}$, a long-lived tracer whose chemical rate of change is negligible on the weekly to monthly timescales considered here. Periods and locations for which significantly non-zero $\mathrm{N}_{2} \mathrm{O}$ rates of change are calculated are therefore indicative of errors in the transport calculations used in the Match approach, for example due to errors in the wind fields and/or biases introduced by their interpolation to the trajectory locations. The two main routes whereby such transport errors can affect inferred ozone loss rates are inaccuracies in the trajectory calculations' depiction of diabatic descent within the polar vortex and of mixing across the polar vortex edge. Inaccurate quantification of both of these processes, along with other transport errors (such as potentially erroneous identification of the matches themselves), will all contribute to errors in the ozone loss estimates. However, disentangling all these contributions is not feasible (at least not when only one long-lived trace gas, such as $\mathrm{N}_{2} \mathrm{O}$, is considered). Accordingly, for simplicity we compute two estimates of the potential contributions of such transport errors to our ozone loss calculations by assuming that the observed $\mathrm{N}_{2} \mathrm{O}$ changes are exclusively due to errors either in descent or in mixing, calculating the magnitude of the transport errors required to explain the observed $\mathrm{N}_{2} \mathrm{O}$ behavior in each case, and then inferring their corresponding impact on ozone loss 


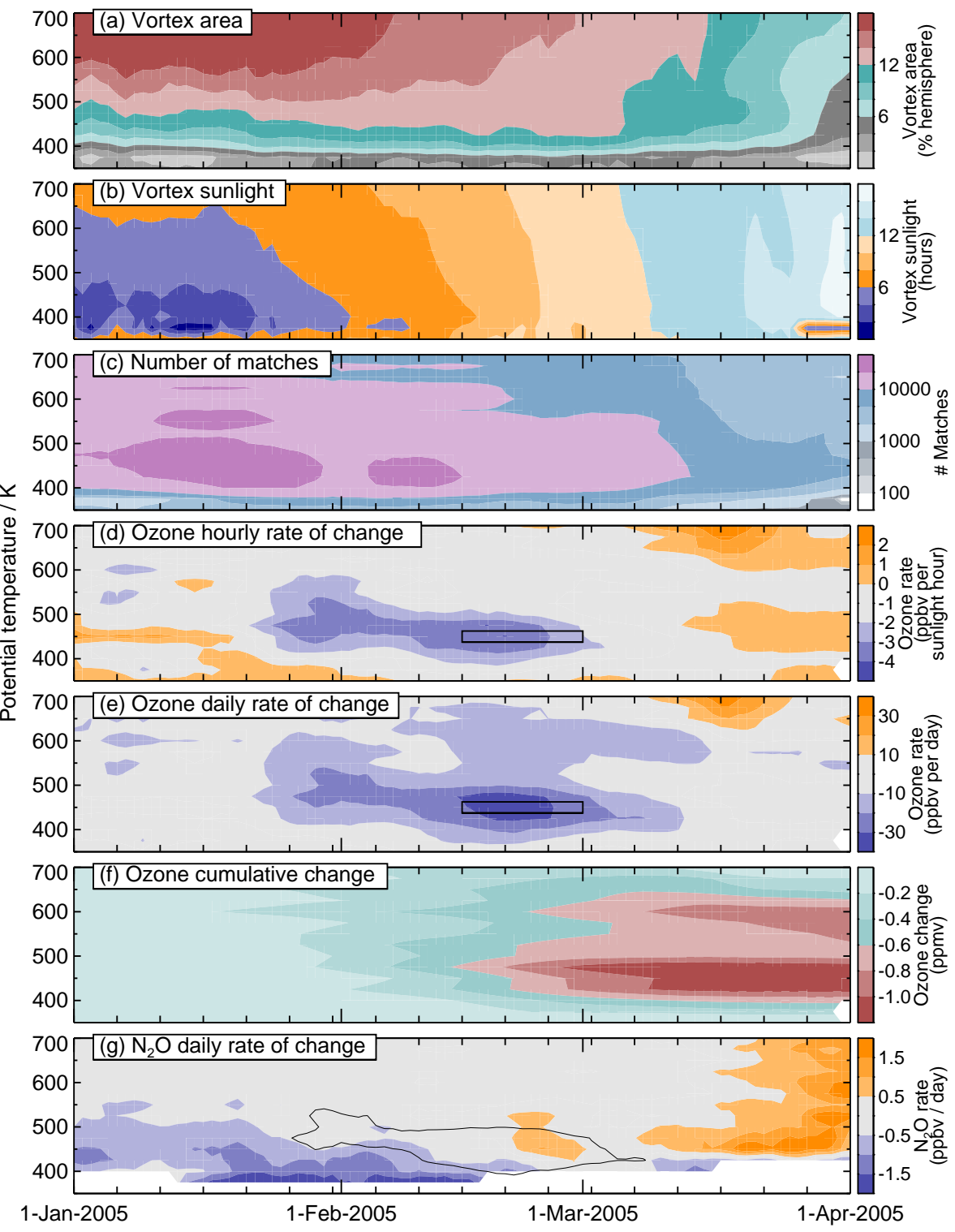

Figure 3. Temporal evolution of various height-resolved quantities during the 2004/05 Arctic winter. (a) Polar vortex area (area within $\mathrm{sPV}>1.4 \times 10^{-4} \mathrm{~s}^{-1}$ ), expressed as a fraction of a hemisphere (grays are small areas, cyans and reds are larger). (b) Average daily sunlight exposure time of air within the vortex (purples are low values, oranges are medium and cyans high). (c) Number of MLS matches in the vortex within a 15 day moving window in $25 \mathrm{~K}$-thick potential temperature layers (white indicates no matches; greys, cyans and reds indicate increasing numbers of matches). (d) Estimated ozone loss rate per sunlight hour (purples are losses, oranges are production; the black box highlights period and altitude range used in Figs. 1 and 2). (e) As in (d) but for loss rate per day. (f) Cumulative ozone change (cyans are small losses, reds are larger). (g) $\mathrm{N}_{2} \mathrm{O}$ daily rate of change (purples are losses, oranges are production). The $-20 \mathrm{ppbv}^{-1} \mathrm{Oy}^{-1} \mathrm{O}_{3}$ contour from (e) is overlaid on $(\mathbf{g})$ in black.

estimates. We refer to these two error estimates as the "descent assumption" and the "mixing assumption" hereinafter. We quantify such errors on a daily basis according to the following:

potential error in $\frac{\partial \mathrm{O}_{3}}{\partial t}=\frac{\partial \mathrm{N}_{2} \mathrm{O}}{\partial t} \frac{\partial \mathrm{O}_{3}}{\partial x} / \frac{\partial \mathrm{N}_{2} \mathrm{O}}{\partial x}$, where $x$ is potential temperature for errors in descent and equivalent latitude for vortex mixing errors (with gradients in the latter case taken at the vortex edge).

During the 2004/05 Arctic winter, our method estimates peak $\mathrm{N}_{2} \mathrm{O}$ changes of $\sim 2$ ppbv (parts per billion by volume) per day (Fig. 3g), compared to typical lower stratospheric $\mathrm{N}_{2} \mathrm{O}$ abundances during this period of $\sim 50 \mathrm{ppbv}$ within the vortex and $\sim 150$ ppbv outside. Figure 4 shows 

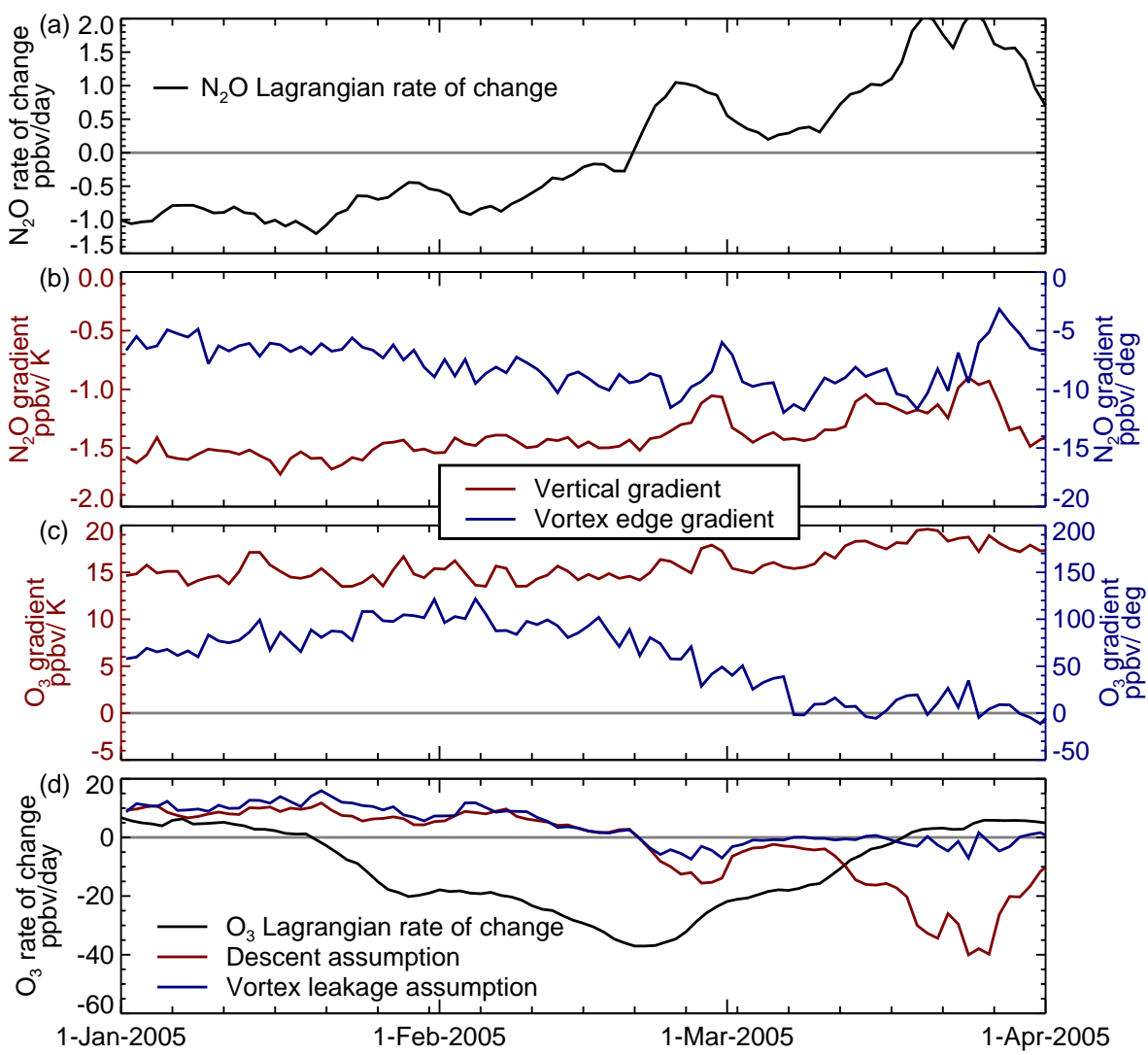

Figure 4. (a) Estimated $450 \mathrm{~K} \mathrm{~N}_{2} \mathrm{O}$ Lagrangian rate of change. (b) $450 \mathrm{~K}$ vortex-average $\mathrm{N}_{2} \mathrm{O}$ vertical gradients (red lines, left hand axes) and $\mathrm{N}_{2} \mathrm{O}$ gradients with respect to equivalent latitude at the vortex edge (blue lines, right hand axes). (c) as (b) but for $\mathrm{O}_{3}$. (d) Reported $450 \mathrm{~K} \mathrm{O}_{3}$ Lagrangian rate of change (i.e., estimated creation or loss rate, black line), and potential contributions to $\mathrm{O}_{3}$ rate of change from transport errors estimated via the descent (red line) or mixing (blue line) assumptions.

the terms in Eq. (1) at $450 \mathrm{~K}$ for each day in the 2004/05 Arctic winter. The $\mathrm{N}_{2} \mathrm{O}$ rate (Fig. $4 \mathrm{a}$ ) remains between -0.5 and -1 ppbv day $^{-1}$ from early January through mid February, following which it increases, reaching a peak around 2 ppbv day ${ }^{-1}$ in late March. The vertical $\mathrm{N}_{2} \mathrm{O}$ gradient (red line in Fig. 4b) generally remains about $-1.5 \mathrm{ppbv} \mathrm{K}^{-1}$, though it becomes slightly more variable in March, sporadically reaching values of $-1.0 \mathrm{ppbv} \mathrm{K}^{-1}$. The $\mathrm{N}_{2} \mathrm{O}$ gradient across the vortex edge (blue line) is similarly constant, remaining between -5 and -10 ppbv per degree of equivalent latitude. Ozone (Fig. 4c), by contrast, while showing little variability in its vertical gradient (which largely remains between 15 and $20 \mathrm{ppbv} \mathrm{K}^{-1}$ ), displays strong variations in its gradient across the vortex edge, starting around 50 ppbv degree $^{-1}$, peaking around 100 ppbvdegree $^{-1}$, and reaching a low around 0 ppbv degree ${ }^{-1}$ in mid-March. Figure $4 \mathrm{~d}$ shows the potential transport error contributions to ozone rates of change, estimated from Eq. (1), and compares them to the rate of change from the ozone Match computations (black line).

During the late-January to early-March period of strongest ozone loss $\left(20-30\right.$ ppbv day $\left.^{-1}\right)$ at $450 \mathrm{~K}$, the potential trans- port error contributions to estimated ozone loss typically remain within $\pm 10 \mathrm{ppbv}$ day $^{-1}$ individually, with the two assumptions giving similar estimates. In late February, while the mixing assumption leads to a $\sim 5$ ppbv day $^{-1}$ contribution to ozone loss, the descent assumption gives as much as $\sim 15 \mathrm{ppbvday}^{-1}$. During the major final warming in late March, while the mixing assumption estimates transport error contributions to ozone rates of change within \pm 5 ppbv day $^{-1}$, the descent assumption yields a potential contribution of as much as $40 \mathrm{ppbv}$ day $^{-1}$ additional loss.

The errors in the integrated ozone loss over each winter corresponding to the descent assumption and the mixing assumption are estimated by computing the sum over all days of the absolute value of the corresponding daily error estimates. This rather pessimistic approach was chosen because the large day-to-day correlations seen in the individual estimates (e.g., both methods consistently give around $10 \mathrm{ppbv}$ day $^{-1}$ each day in January) make root sum square aggregation (which assumes that errors vary randomly from day to day and thus "average out" in an integrated total) unreasonably optimistic. 
In general, it is not possible to quantify the extent to which inaccuracies in descent vs. mixing have contributed to transport errors, and thence to non-zero estimates of the $\mathrm{N}_{2} \mathrm{O}$ rate of change. However, in certain circumstances insights into such partitioning are possible. For example, the ozone Match calculation shows no significant losses during late March at $450 \mathrm{~K}$ (actually indicating a, likely erroneous, $\sim 5$ ppbv day $^{-1}$ increase in ozone). No loss in ozone is expected during this period, as chlorine has been deactivated (Santee et al., 2008). Accordingly, the non-zero $\mathrm{N}_{2} \mathrm{O}$ rate computed during this period most likely results from errors in the characterization of vortex edge mixing, as descent errors would result in large ozone changes also being estimated. Errors in mixing calculations during this period will have little impact on ozone rates given the low gradient in ozone across the vortex edge, whereas they will strongly affect $\mathrm{N}_{2} \mathrm{O}$, for which gradients across the vortex edge remain strong.

Factoring in Match-based estimates of the rate of change of other tracer species observed by MLS, such as methyl chloride and, in certain circumstances, water vapor, may enable a more systematic partitioning of transport errors between descent and mixing. However, such work is beyond the scope of this study, and we will simply report separate error estimates based on the descent and mixing assumptions hereinafter.

\subsection{Aside: placing constraints on nighttime ozone loss}

In parallel with loss calculations described above, we also estimated, for each 15 day running window, hourly ozone loss rates partitioned between sunlight (defined as having the sun at least $1^{\circ}$ above the local horizon), darkness (at least $1^{\circ}$ below) and twilight (between the two). This computation was performed to further rule out alternative mechanisms for polar ozone loss not requiring sunlight. Such mechanisms were proposed in response to laboratory measurements of chlorine dimer cross sections (Pope et al., 2007) that appeared to challenge the generally accepted understanding of polar ozone loss. These mechanisms have, however, increasingly been shown to be unlikely (World Meteorological Organization, 2014), and more recent laboratory measurements of the same cross sections (Papanastasiou et al., 2009) are more in line with earlier findings than with the Pope et al. value.

Rex et al. (1998) used ozonesonde-based matches to estimate day/night ozone loss partitioning during 1 January to 9 February 1992, finding no significant nighttime loss. Application of the same approach with MLS Match gives mixed results. The ability to estimate loss diurnal partitioning is dependent on the degree to which the air masses considered experience diverse ratios of sunlight vs. darkness exposure. Calculations for periods such as early in the Antarctic spring, when some air masses (e.g., those circulating within the vortex core) experience continuous darkness while others are episodically exposed to sunlight, yield robust partitioning estimates. However, it transpires that, in both hemispheres, the

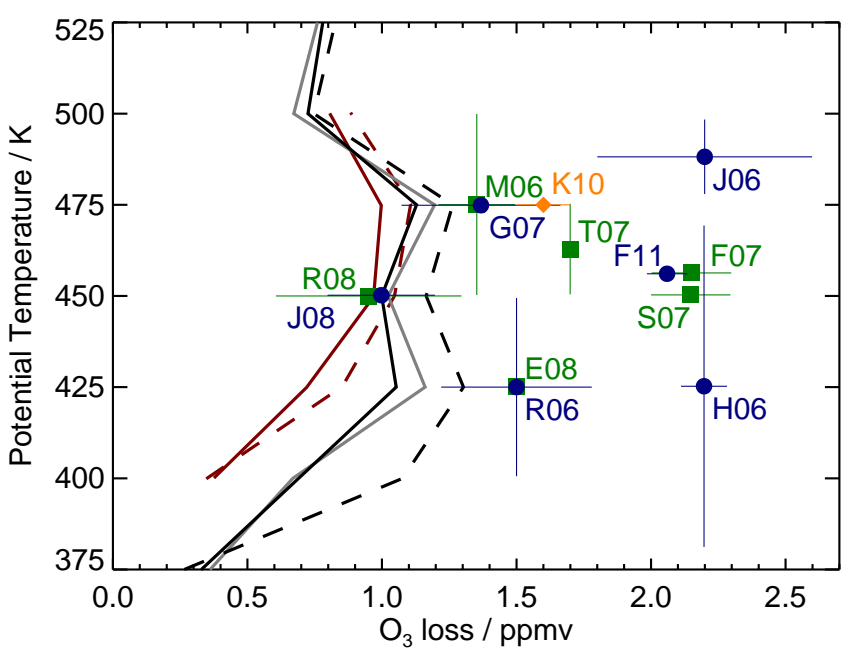

Figure 5. Vortex average ozone loss from 1 January to 1 April 2005 , computed using our method with the "standard" criteria (black solid line) and computed using only those observations more deeply within the polar vortex $\left(\mathrm{sPV} \geq 1.6 \times 10^{-4} \mathrm{~s}^{-1}\right.$, black dashed line), along with comparable estimates from Brakebusch et al. (2013), upon whose Fig. 11 this plot is based (we repeat their "inferred" rather than "modeled" results, shown here by the red solid and dashed lines, using the same vortex edge criteria as for MLS). Also shown are the MLS results using the "stricter" PV variability criterion (grey line) and, as in the Brakebusch figure, results from other studies (green, blue and orange symbols) listed in Table 1, with colors used simply to aid distinction between results (the Kuttippurath et al., 2010, result is singled out in orange as it did not feature in the Brakebusch figure).

air mass trajectories considered in many 15 day periods during times of peak loss collectively experience roughly the same ratio of sunlight to darkness, offering little ability to discriminate the loss during daylight conditions from that taking place at night. In these cases the covariance information obtained from the fits shows that estimates of the difference in loss rate between daylight and non-daylight (i.e., night or twilight) conditions are as much as 10 times less certain than the estimated total "daily" loss rate (i.e., the average loss rate in a given $24 \mathrm{~h}$ period regardless of illumination). Accordingly, while nighttime ozone loss can be shown to be negligible in certain regions/periods, it is not possible to use this approach to definitively rule out nighttime loss under all circumstances.

\section{Comparison to previous estimates of ozone loss in the 2004/05 Arctic winter}

Figure 5 and Table 1 compare our estimated ozone loss profile for the well-studied 2004/05 Arctic winter to profile and layer/level estimates from other studies. Our method (solid black line) is in broad agreement with findings from previous studies, though lower than most. As expected (e.g., from 
Table 1. Previous quantifications of ozone loss during the 2004/05 Arctic winter.

\begin{tabular}{|c|c|c|c|c|c|}
\hline Code & Study & Approach [model] (observations) & $\begin{array}{l}\text { Ozone loss } \\
\text { /ppmv }\end{array}$ & $\begin{array}{l}\text { Vertical } \\
\text { range/K }\end{array}$ & Period \\
\hline M06 & Manney et al. (2006) & Vortex average descent (Aura MLS) & $1.2-1.5$ & $450-500$ & Jan-mid-Mar \\
\hline J06 & Jin et al. (2006) & $\begin{array}{l}\text { Various descent and correlation methods } \\
\text { (ACE FTS) }\end{array}$ & $1.8-2.6$ & $465-500$ & 1 Jan-mid-Mar \\
\hline R06 & Rex et al. (2006) & Match (ozonesonde), also descent (POAM/SAGE) & $0.6-1.8$ & $400-450$ & 5 Jan-25 Mar \\
\hline H06 & von Hobe et al. (2006) & Tracer correlation (aircraft in situ) & $2.1-2.3$ & $380-470$ & Jan-7 Mar \\
\hline F07 & W. Feng et al. (2007) & Passive subtraction [SLIMCAT] (ozonesonde) & $2.0-2.3$ & 456 & Dec-Mar \\
\hline G07 & Grooß and Müller (2007) & $\begin{array}{l}\text { Passive subtraction [CLaMS] } \\
\text { (Aura MLS, ACE FTS) }\end{array}$ & $1.1-1.7$ & 475 & Jan-Mar \\
\hline S07 & Singleton et al. (2007) & $\begin{array}{l}\text { Passive subtraction [SLIMCAT] (Aura MLS, } \\
\text { ACE FTS and MAESTRO, SAGE III, POAM III) }\end{array}$ & $2.0-2.3$ & 450 & Dec-mid-Mar \\
\hline T07 & Tsvetkova et al. (2007) & Vortex average descent (SAGE-III) & 1.7 & $450-475$ & 1 Jan-25 Mar \\
\hline E08 & El Amraoui et al. (2008) & Vortex average descent (Aura MLS) & 1.5 & 425 & 10 Jan-10 Mar \\
\hline J08 & Jackson and Orsolini (2008) & $\begin{array}{l}\text { Passive subtraction [MetOffice] } \\
\text { (MLS/SBUV assimilation) }\end{array}$ & $0.8-1.2$ & 450 & Jan-early Mar \\
\hline R08 & Rösevall et al. (2008) & $\begin{array}{l}\text { Passive subtraction [DIAMOND] } \\
\text { (Aura MLS, Odin SMR) }\end{array}$ & $0.7-1.1$ & $430-460$ & 1 Jan-mid-Mar \\
\hline F11 & Feng et al. (2011) & Passive subtraction [SLIMCAT] (Aura MLS) & $2.0-2.1$ & 456 & Dec-Mar \\
\hline B13 & Brakebusch et al. (2013) & Passive subtraction [WACCM] (Aura MLS) & 0.9 & 450 & Dec-7 Mar \\
\hline - & This work & Match (Aura MLS) & $1.0-1.2$ & 450 & 1 Jan-1 Apr \\
\hline
\end{tabular}

Grooß et al., 2008), using a larger sPV value for the vortex edge (dashed black line) increases the estimated losses by $\sim 20 \%$, a somewhat larger increase than that reported by Brakebusch et al. (2013, red solid and dashed lines) using a passive subtraction approach based on MLS observations and the Whole Atmospheric Community Climate Model (WACCM). The stricter $10 \% \mathrm{sPV}$ variability criterion (grey line) also increases our estimated loss, though to a much lesser degree. Estimates of peak ozone loss that winter from all the studies shown here range from around 1.0 ppmv (our study, as well as Rösevall et al., 2008 and Jackson and Orsolini, 2008), to as high as $2.2 \mathrm{ppmv}$ (Jin et al., 2006; von Hobe et al., 2006). This wide range reflects the challenges associated with quantifying chemical ozone loss in a manner that properly accounts for transport processes. The range here is comparable to that seen in earlier winters (e.g., Harris et al., 2002).

There is no clear pattern to the variations among the estimates reported; no one approach, model, or measurement technique consistently yields large or small losses. Rather, the diversity seems to be driven by individual choices made by the investigators, such as the time period over which the loss was estimated and the choice of vortex edge criterion. For the passive subtraction studies employing a full chemistry transport model, important factors include the choice of whether it is the observed or model simulated ozone from which the modeled passive ozone is subtracted, and/or any methods used to correct for biases in the model ozone fields (e.g., as discussed in Jackson and Orsolini, 2008).

\section{Arctic and Antarctic ozone loss estimates, 2004-2012}

Figure 6 shows integrated losses for each of the Arctic and Antarctic winters observed by MLS through March 2013. As expected (e.g., Manney et al., 2011; World Meteorological Organization, 2014), Arctic ozone loss is by far the greatest in the 2010/11 winter, with 2 ppmv loss estimated at $450 \mathrm{~K}$ (the 26 March end date for this estimate was necessitated by an anomalous temporary shutdown of the MLS instrument; normal operations resumed on 19 April 2011). Consistent with our comparisons for the 2004/05 winter, this estimate is in reasonable agreement with those from other studies, though on the low side. Manney et al. (2011) estimate $\sim 2.5 \mathrm{ppmv}$ of loss at $450 \mathrm{~K}$ based on both MLS and ozonesonde observations, while Kuttippurath et al. (2012) estimate $\sim 2.5$ ppmv loss at $475 \mathrm{~K}(\sim 19 \mathrm{~km})$ using subtraction of passive ozone (derived by the "Mimosa-Chim" model) from MLS observations. Sinnhuber et al. (2011) estimate $2.2 \mathrm{ppmv}$ at the same level using Michelson Interferometer for Passive Atmospheric Sounding (MIPAS) ozone observations (von Clarmann et al., 2009) and passive subtraction. Large losses of around $1 \mathrm{ppmv}$ are also found in our results at $450 \mathrm{~K}$ during the 2004/05, 2006/07 and 2007/08 winters. However, at $400 \mathrm{~K}$, significant losses are only seen in the 2004/05 and 2010/11 winters (both $\sim 0.7$ ppmv).

The 2005/06, 2008/09, 2011/12, and 2012/13 Arctic winters have the smallest losses, in many cases indistinguishable from zero when possible transport errors are factored in. These winters featured sudden stratospheric warmings (SSWs) that resulted in early chlorine deactivation (e.g., Manney et al., 2008, 2009; Coy and Pawson, 2015; Manney 


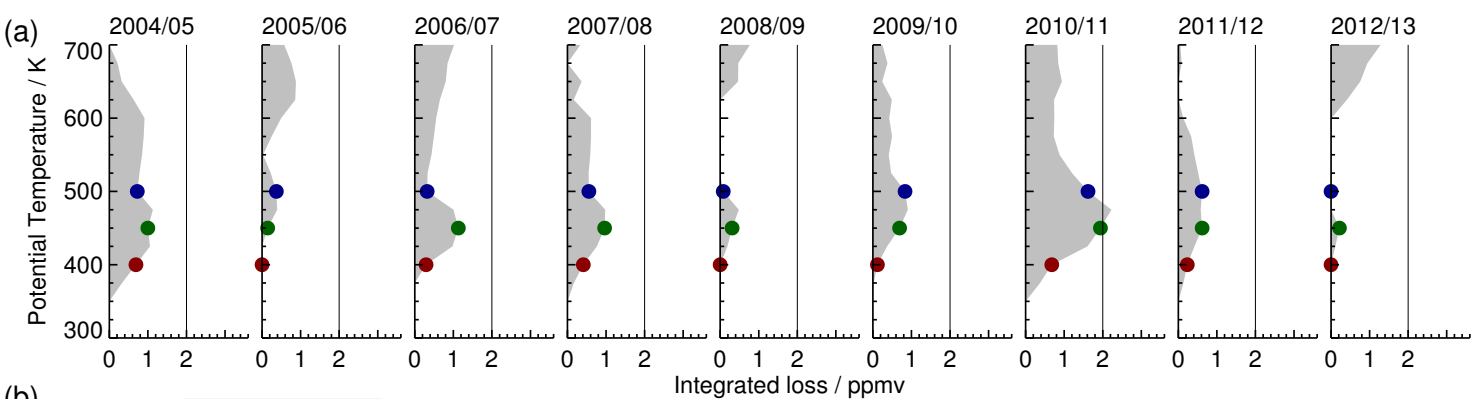

(b)

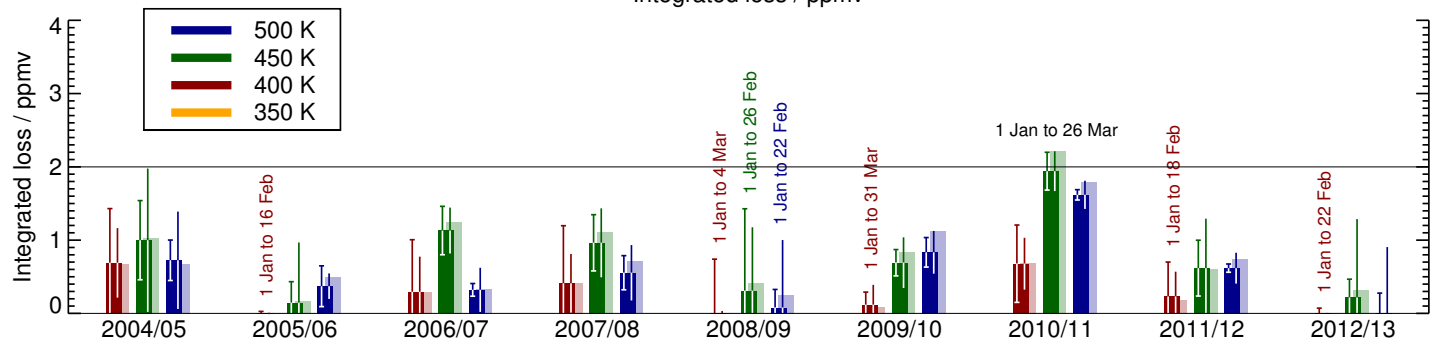

(c)

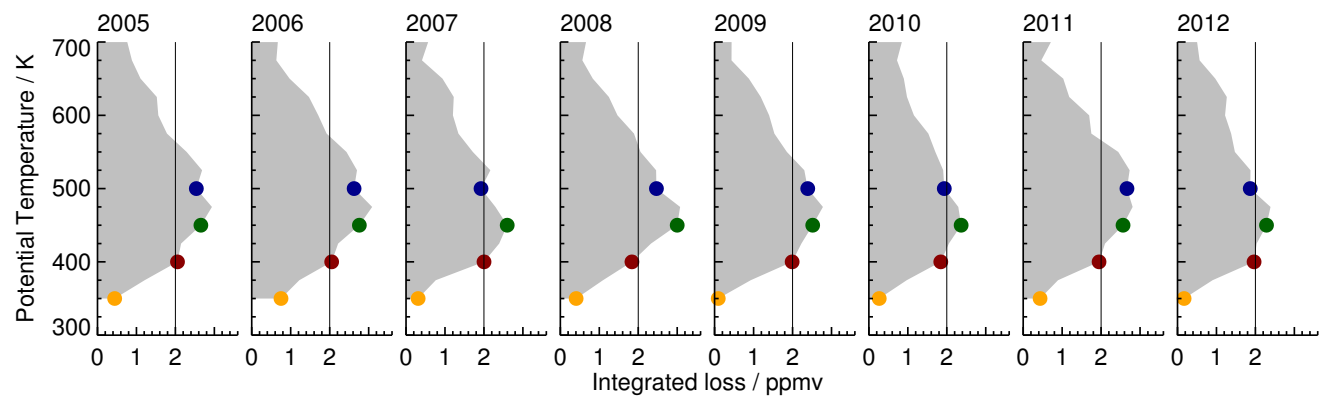

(d)

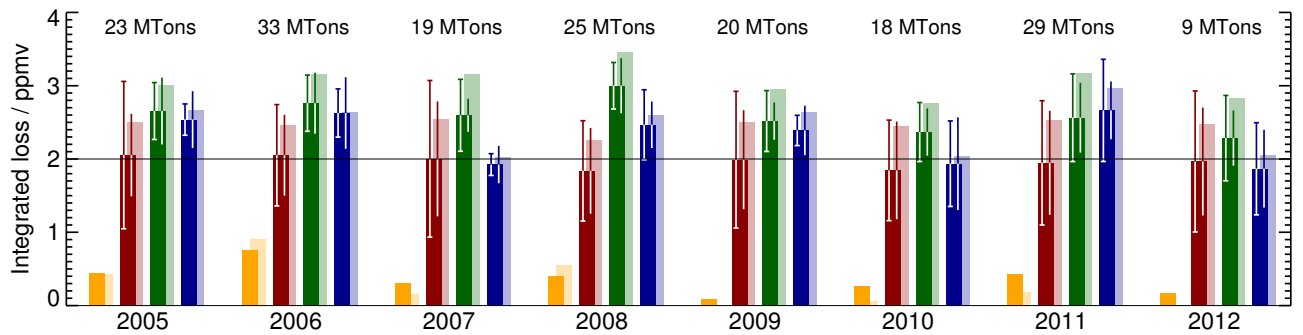

Figure 6. Integrated ozone loss for each Arctic winter from 1 January to 1 April each year for 2004/05 to 2012/13 (a and b) and Antarctic winter from 1 June to 15 October for 2005 to 2012 (c and d). Occasional shorter periods in the Arctic, owing to vortex breakdown at some altitudes and a March 2011 MLS instrument anomaly, are noted in (b). (a) and (c) show vertical profiles of ozone loss (grey shading) each season. Colored points highlight the altitudes shown in the bar charts in (b) and (d). Results shown in strong colors in (b) and (d) are for the "standard" match criteria, with paler colors showing results from the "stricter" calculation (sPV variability $<10$ vs. $25 \%$ ). Error bars on the standard results are $\mathrm{N}_{2} \mathrm{O}$-based estimates of contributions from transport errors using the "mixing" (left hand error bars with horizontal caps) and "descent" assumptions (right hand error bars), respectively. These are omitted for the $350 \mathrm{~K}$ (orange) bars in (d) as this altitude is typically below the level at which MLS $\mathrm{N}_{2} \mathrm{O}$ data are scientifically useful. (d) also includes the October-average "ozone mass deficit" (taken from the "Ozone Watch" website, http://ozonewatch.gsfc.nasa.gov).

et al., 2015). During these winters there were periods when the circulation was sufficiently disturbed that no meaningful polar vortex could be defined (none of the vortex fragments that remained encompassed more than $1 \%$ of a hemisphere). Moderate losses are estimated for the 2009/10 winter, consistent with the later SSW that winter than in the low loss years, and an exceptionally cold phase in early January 2010, which promoted greater chlorine activation (e.g., World Meteorological Organization, 2014).

Manney et al. (2015) discuss the Arctic 2012/13 winter in more detail, including use of the MLS Match approach described here to quantify ozone loss in the early stages (December and January) of that unusual winter. They also show calculations at $490 \mathrm{~K}(\sim 20 \mathrm{~km})$ from trajectory-based passive subtraction (as per Manney et al., 2003 and references 
Table 2. Comparison of lower stratospheric column ozone loss estimates with those from Kuttippurath et al. (2010), with Kuttippurath et al. (2012) used for 2010/11. All losses are quoted in Dobson Units (DU).

\begin{tabular}{llllllll}
\hline $350-850 \mathrm{~K}$ & $2004 / 05$ & $2005 / 06$ & $2006 / 07$ & $2007 / 08$ & $2008 / 09$ & $2009 / 10$ & $2010 / 11$ \\
\hline This work & 75 & 24 & 64 & 60 & 22 & 42 & 116 \\
Kuttippurath et al. & 115 & 26 & 84 & 112 & 38 & 60 & 130 \\
This work (EqL) & 70 & 24 & 61 & 64 & 24 & 41 & 105 \\
\hline $350-550 \mathrm{~K}$ & & & & & & & \\
\hline This work & 88 & 10 & 54 & 66 & 10 & 44 & 117 \\
Kuttippurath et al. & 81 & 14 & 62 & 90 & 28 & 42 & 115 \\
This work (EqL) & 84 & 11 & 51 & 71 & 12 & 48 & 108 \\
\hline
\end{tabular}

therein) using MLS data. Their results indicate slightly larger early winter (December/January) ozone loss in 2012/13 than the MLS Match method used here, and very similar patterns of interannual variability to the MLS Match-derived December/January chemical loss.

Antarctic losses in all years in the record and at all altitudes are larger than any seen in the Arctic at the same altitude level. The vertical profile of Antarctic loss is broader than that in the Arctic, with at least $\sim 1 \mathrm{ppmv}$ of loss seen from 400 to $625 \mathrm{~K}(\sim 16-25 \mathrm{~km})$ each year. Antarctic losses at $350 \mathrm{~K}$ vary significantly, ranging from $0.1 \mathrm{ppmv}$ to as much as 0.7 ppmv. By contrast, losses at $400 \mathrm{~K}$ are less variable, being between 1.8 and 2.1 ppmv in all years. Greater interannual variability is again seen at higher altitudes, with losses between 2.3 and 3.0 ppmv at $450 \mathrm{~K}$, and between 1.9 and $2.7 \mathrm{ppmv}$ at $500 \mathrm{~K}$. The overall variability in ozone loss exhibits an inconsistent relationship with the reported "ozone mass deficit" (World Meteorological Organization, 2007), an estimate of the mass difference between satellite-observed column ozone and a nominal 220-DU column abundance. The 2 years in our record with the smallest mass deficits are $2012(9 \mathrm{Mt})$ and 2010 (18 Mt), both years for which our calculations show 2.3-2.4 ppmv loss at $450 \mathrm{~K}$, less than is typical. By contrast, for 2006, which has the greatest deficit (33 Mt) seen during the Aura mission, our calculations show chemical ozone losses that are, at most altitudes, very similar to those in 2005 (e.g., $\sim 2.6$ ppmv at $450 \mathrm{~K}$ ), when the mass deficit was only $23 \mathrm{Mt}$. Santee et al. (2011) reported unusually low temperatures and prolonged chlorine activation in the lowermost Antarctic vortex and "subvortex" during the 2006 winter, and suggested that the consequent unusually large degree of ozone loss at these low altitudes contributed significantly to the record depth, extent and mass deficit of the ozone hole that year. Their inference is consistent with Fig. 6d, which shows that 2006 stands out as having the largest losses at $350 \mathrm{~K}(\sim 0.8 \mathrm{ppmv})$ in the MLS record. Santee et al. (2011) reported similar, though less pronounced, behavior during 2008, a year when the ozone mass deficit is also large $(25 \mathrm{Mt})$, and for which we estimate $\sim 0.4 \mathrm{ppmv}$ loss at $350 \mathrm{~K}$. However, we note that, while both our method and the ozone mass deficit show 2008 as being similar in many regards to 2005, the latter year does not stand out in the Santee et al. (2011) record as having notably depleted lowermost stratospheric ozone in the Antarctic vortex, a disparity that bears further model-based investigation.

The "stricter" $10 \% \mathrm{PV}$ divergence criterion generally results in larger ozone loss estimates, particularly in the Antarctic, where an additional $\sim 0.5 \mathrm{ppmv}$ loss is estimated at 400 and $450 \mathrm{~K}(\sim 0.0$ to $0.3 \mathrm{ppmv}$ at $500 \mathrm{~K})$. In the Arctic this criterion results in up to $\sim 0.3$ ppmv additional loss. The $\mathrm{N}_{2} \mathrm{O}$-based transport error estimates for the Antarctic have roughly the same magnitude each year, and are generally largest at $400 \mathrm{~K}$, around $\pm(0.5-1.0)$ ppmv. In the Arctic, these estimates indicate far greater confidence in the large degree of loss during the 2010/11 Arctic winter than is seen for $2004 / 05$ ( \pm 0.3 vs. \pm 1.0 ppmv at $450 \mathrm{~K}$ ). This is consistent with Manney et al. (2015), who note significantly larger errors in passively transported $\mathrm{N}_{2} \mathrm{O}$ during periods with more disturbed vortices and more mixing. Conversely, while the "stricter" PV criterion has little impact on 2004/05 loss estimates, it does give $0.3 \mathrm{ppmv}$ greater loss at $450 \mathrm{~K}$ during 2010/11.

Table 2 compares Arctic column ozone loss estimates from our approach (computed from the mixing ratio losses given in Fig. 6 using the mean vortex-average GEOS-5 temperature profile for each winter period to estimate density for a given pressure level) to those reported by Kuttippurath et al. (2010, 2012) based on comparison of MLS observations to passive ozone from the Mimosa-Chim model. In the lower stratosphere $(350-550 \mathrm{~K}, \sim 13-22 \mathrm{~km})$, the two approaches agree within $\sim 8 \mathrm{DU}$, except for 2008/09, a winter with very little ozone loss, and, more significantly, 2007/08. The latter winter is estimated by Kuttippurath et al. $(2010,2012)$ to have the second largest column loss over this altitude range in the MLS record; our study ranks it third. Estimates of column loss over a broader vertical range $(350-850 \mathrm{~K}, \sim 13-$ $31 \mathrm{~km}$ ) indicate that the Kuttippurath approach generally reports $\sim 20-50$ DU more loss than our method.

We note that Kuttippurath et al. (2010) used an equivalent latitude-based vortex edge criterion, rather than the sPV 
criterion used for our study. Although equivalent latitude is less suitable in cases where the vortex area changes significantly with time, in order to allow a more direct comparison we have included results from our "MLS Match" approach using the Kuttippurath et al. (2010) $65^{\circ}$ equivalent latitude criterion in Table 2. The differences between the two MLS Match-based estimates are nearly all smaller than the differences between either and the Kuttippurath et al. results.

\section{Summary of findings and future work}

Applying the well-established Match technique to MLS observations of polar lower stratospheric ozone has enabled a new systematic quantification of ozone loss for the Arctic winters from 2004/05 to 2012/13 and the Antarctic winters from 2005 to 2012. While ozonesonde-based studies of polar ozone loss have access to hundreds of matched observations per winter, the MLS Match approach yields thousands per day, making the ozone loss estimates insensitive to noise on the MLS observations. Uncertainties in loss therefore largely result from errors in transport calculations. Sensitivity studies for the 2004/05 Arctic winter (representative of others studied) indicate that loss estimates are not significantly affected by limits set on how close the initially observed air mass has to be to the second observation, nor by limits on how far apart the two trajectories launched in the environs of the first observation are allowed to spread. Loss estimates are, however, impacted by the choice of sPV value used as a vortex edge criterion, with larger absolute sPV thresholds often giving greater loss estimates, consistent with past findings that loss is, in many cases, greater in the vortex core region than at the edge. The other factor influencing loss estimates is the extent to which the sPV of the tracked air masses is allowed to vary in the time between the two observations, with more stringent criteria giving larger loss estimates, consistent with expectations that processes, such as sub-grid-scale mixing, that introduce PV variability also act to mitigate chemical ozone destruction. Applying the same Match methodology to MLS observations of $\mathrm{N}_{2} \mathrm{O}$ and attributing any non-zero rates of change to problems with transport calculations enables estimation of the potential impact of these transport errors on ozone loss estimates. This is accomplished through scaling arguments that consider these transport errors to be purely due to shortcomings in the depiction of either mixing or decent.
Comparisons of ozone loss estimates from this approach with those obtained by other methods, and using other sensors, indicate generally consistent results, though our estimates are smaller than most. Systematically applying this approach to all the Arctic winters observed by MLS from $2004 / 05$ to $2012 / 13$ shows the expected large degree of interannual variability, with strong losses seen in 2004/05 and 2010/11, and very little integrated loss seen in 2005/06, 2008/09 and 2012/13. In contrast with Arctic ozone loss estimates (e.g., ranging from $0.2-1.9 \mathrm{ppmv}$ at $450 \mathrm{~K}$ ), Antarctic ozone losses are larger and more stable (e.g., being within 2.3 to $3.0 \mathrm{ppmv}$ at $450 \mathrm{~K}$ ). The relationship between Antarctic ozone loss estimates and ozone hole metrics such as the "ozone mass deficit" is unclear. While less loss is seen in years with notably small and shallow holes, years with extensive deep holes show comparable loss to years with more moderate ozone hole metrics. However, our study does corroborate previous suggestions (Santee et al., 2011) that ozone loss in the lowermost stratosphere was a significant contributor to the record depth of the 2006 ozone hole.

Applying the "stricter" sPV criterion results in greater estimates of ozone loss, particularly in the Antarctic (with $\sim 0.5$ ppmv additional loss at 400 and $450 \mathrm{~K}$ being typical). The $\mathrm{N}_{2} \mathrm{O}$-based transport error estimates generally indicate uncertainties around $0.5 \mathrm{ppmv}$, though there is notable variability in this estimate with, for example, greater confidence shown in the Arctic ozone loss estimates for 2010/11 than 2004/05.

Future work extending the MLS Match approach to other species may enable additional quantification of processes previously studied using MLS observations, such as chlorine activation and denitrification (e.g., Santee et al., 2008; Lambert et al., 2012). In addition, consideration of more longlived tracers in conjunction with $\mathrm{N}_{2} \mathrm{O}$ may enable systematic quantification of transport errors in the trajectory calculations, and hence provide a metric of the accuracy of wind and heating rate fields. 


\section{Appendix A: MLS Lagrangian trajectory diagnostics}

The MLS Lagrangian trajectory diagnostics (LTDs) upon which this analysis is based are publicly available as an additional MLS diagnostic product, in "reduced" form to facilitate easier download and usage (available from http://mls. jpl.nasa.gov/data/ltd.php). The reduced LTDs differ from the full LTDs described in the text above, in that they give the location of the parcels only every $2 \mathrm{~h}$ (rather than at the original $20 \mathrm{~min}$ intervals), with the locations of the flanking trajectories omitted and replaced by a simple measure of the distance between the flanking and "central" trajectories. These simplifications reduce the file volume from $\sim 7.4 \mathrm{~Gb}$ to $\sim 700 \mathrm{Mb}$ per day of the MLS mission, giving a rough mission-to-date (10+ years) total of $\sim 2.5 \mathrm{~Tb}$.

Planned applications for the LTDs beyond Match calculations include the quantification of convective influence to tropical and subtropical upper tropospheric air masses observed by MLS, as previously implemented for highaltitude aircraft in situ observations (Pfister et al., 2001, 2010; Sayres et al., 2010), and the generation of high resolution "trajectory-mapped" fields such as previously implemented by Schoeberl et al. (2007). 
Acknowledgements. This work benefited from several helpful conversations with Markus Rex. Thanks also to Michael Schwartz, Alyn Lambert and Zachary Lawrence for providing feedback and comments on the MLS LTDs. Work at the Jet Propulsion Laboratory, California Institute of Technology was performed under a contract with the National Aeronautics and Space Administration.

Edited by: W. Lahoz

\section{References}

Anderson, J. G., Brune, W. H., and Proffitt, M. H.: Ozone destruction by chlorine radicals within the Antarctic vortex: the spatial and temporal evolution of $\mathrm{ClO}-\mathrm{O}_{3}$ anticorrelation based on in situ ER-2 data, J. Geophys. Res., 94, 11465-11479, 1989.

Andrews, D. G.: Some comparisons between the middle atmosphere dynamics for the Southern and Northern Hemispheres, Pure Appl. Geophys., 130, 213-232, 1989.

Brakebusch, M., Randall, C. E., Kinnison, D. E., Tilmes, S., Santee, M. L., and Manney, G. L.: Evaluation of Whole Atmosphere Community Climate Model simulations of ozone during Arctic winter 2004-2005, J. Geophys. Res., 118, 2673-2688, doi:10.1002/jgrd.50226, 2013.

Butchart, N. and Remsberg, E. E.: The area of the stratospheric vortex as a diagnostic for tracer transport on an isentropic surface, J. Atmos. Sci., 43, 1319-1339, 1986.

Coy, L. and Pawson, S.: The major stratospheric sudden warming of January 2013: analyses and forecasts in the GEOS-5 data assimilation system, Mon. Weather. Rev., 143, 491-510, doi:10.1175/MWR-D-14-00023.1, 2015.

Crutzen, P. J. and Arnold, F.: Nitric-acid cloud formation in the cold Antarctic stratosphere - a major cause for the springtime ozone hole, Nature, 324, 651-655, 1986.

Danilin, M. Y., Santee, M. L., Rodriguez, J. M., Ko, M. K. W., Mergenthaler, J. M., Kumer, J. B., Tabazadeh, A., and Livesey, N. J.: Trajectory hunting: a case study of rapid chlorine activation in December 1992 as seen by UARS, J. Geophys. Res., 105, 40034018, 2000.

Danilin, M. Y., Ko, M. K. W., Froidevaux, L., Santee, M. L., Lyjak, L. V., Bevilacqua, R. M., Zawodny, J. M., Sasano, Y., Irie, H., Kondo, Y., Russell, J. M., Scott, C. J., and Read, W. G.: Trajectory hunting as an effective technique to validate multiplatform measurements: analysis of the MLS, HALOE, SAGE-II, ILAS, and POAM-II data in October-November 1996, J. Geophys. Res., 107, 4420, doi:10.1029/2001JD002012, 2002.

Deniel, C., Bevilacqua, R. M., Pommereau, J. P., and Lefèvre, F.: Arctic chemical ozone depletion during the 1994-1995 winter deduced from POAM II satellite observations and the REPROBUS three-dimensional model, J. Geophys. Res., 103, 19231-19244, doi:10.1029/98JD01446, 1998.

Dunkerton, T. J. and Delisi, D. P.: Evolution of potential vorticity in the winter stratosphere of January-February 1979, J. Geophys. Res., 91, 1199-1208, doi:10.1029/JD091iD01p01199, 1986.

El Amraoui, L., Semane, N., Peuch, V. H., and Santee, M. L.: Investigation of dynamical processes in the polar stratospheric vortex during the unusually cold winter 2004/2005, Geophys. Res. Lett., 35, L03803, doi:10.1029/2007GL031251, 2008.
Esler, J. G. and Waugh, D. W.: A method for estimating the extent of denitrification of Arctic polar vortex air from tracer-tracer scatterplots, J. Geophys. Res., 107, D001071, doi:10.1029/2001JD001071, 2002.

Farman, J. C., Gardiner, B. G., and Shanklin, J. D.: Large losses of total ozone in Antarctica reveal seasonal $\mathrm{ClO}_{\mathrm{x}} / \mathrm{NO}_{\mathrm{x}}$ interaction, Nature, 315, 207-210, 1985.

Feng, L., Harwood, R. S., Brugge, R., O’Neill, A., Froidevaux, L., Schwartz, M., and Waters, J. W.: Equatorial Kelvin waves as revealed by EOS Microwave Limb Sounder observations and European Center for Medium-Range Weather Forecasts analyses: evidence for slow Kelvin waves of zonal wave number 3, J. Geophys. Res., 112, D16106, doi:10.1029/2006JD008329, 2007.

Feng, W., Chipperfield, M. P., Davies, S., von der Gathen, P., Kyro, E., Volk, C. M., Ulanovsky, A., and Belyaev, G.: Large chemical ozone loss in 2004/2005 Arctic winter/spring, Geophys. Res. Lett., 34, L9803, doi:10.1029/2006GL029098, 2007.

Feng, W., Chipperfield, M. P., Davies, S., Mann, G. W., Carslaw, K. S., Dhomse, S., Harvey, L., Randall, C., and Santee, M. L.: Modelling the effect of denitrification on polar ozone depletion for Arctic winter 2004/2005, Atmos. Chem. Phys., 11, 6559-6573, doi:10.5194/acp-11-6559-2011, 2011.

Frieler, K., Rex, M., Salawitch, R. J., Canty, T., Streibel, M., Stimpfle, R. M., Pfeilsticker, K., Dorf, M., Weisenstein, D. K., and Godin-Beekmann, S.: Toward a better quantitative understanding of polar stratospheric ozone loss, Geophys. Res. Lett., 33, L10812, doi:10.1029/2005GL025466, 2006.

Froidevaux, L., Jiang, Y. B., Lambert, A., Livesey, N. J., Read, W. G., Waters, J. W., Browell, E. V., Hair, J. W., Avery, M. A., McGee, T. J., Tiwgg, L. W., Sumnicht, G. K., Jucks, K. W., Margitan, J. J., Sen, B., Stachnik, R. A., Toon, G. C., Bernath, P. F., Boone, C. D., Walker, K. A., Filipiak, M. J., Harwood, R. S., Fuller, R. A., Manney, G. L., Schwartz, M. J., Daffer, W. H., Drouin, B. J., Cofield, R. E., Cuddy, D. T., Jarnot, R. F., Knosp, B. W., Perun, V. S., Snyder, W. V., Stek, P. C., Thurstans, R. P., and Wagner, P. A.: Validation of Aura Microwave Limb Sounder stratospheric and mesospheric ozone measurements, J. Geophys. Res., 113, D15S20, doi:10.1029/2007JD008771, 2008.

Goutail, F., Pommereau, J. P., Phillips, C., Deniel, C., Sarkissian, A., Lefevre, F., Kyro, E., Rummukainen, M., Ericksen, P., Andersen, S. B., Kaastad-Hoiskar, B. A., Braathen, G., Dorokhov, V., and Khattatov, V. U.: Depletion of column ozone in the Arctic during the winters of 1993-94 and 1994-95, J. Atmos. Chem., 32, 1-34, 1999.

Grooß, J. U. and Müller, R.: Simulation of ozone loss in Arctic winter 2004/2005, Geophys. Res. Lett., 34, L5804, doi:10.1029/2006GL028901, 2007.

Grooß, J.-U., Müller, R., Konopka, P., Steinhorst, H.-M., Engel, A., Möbius, T., and Volk, C. M.: The impact of transport across the polar vortex edge on Match ozone loss estimates, Atmos. Chem. Phys., 8, 565-578, doi:10.5194/acp-8-565-2008, 2008.

Harris, N. R. P., Rex, M., Goutail, F., Knudsen, B. M., Manney, G. L., Müller, R., and von der Gathen, P.: Comparison of empirically derived ozone losses in the Arctic vortex, J. Geophys. Res., 107, 8264, doi:10.1029/2001JD000482, 2002.

Hoppel, K., Bevilacqua, R., Nedoluha, G., Deniel, C., Lefèvre, F., Lumpe, J., Fromm, M., Randall, C., Rosenfield, J., and Rex, M.: POAM III observations of arctic ozone loss 
for the 1999/2000 winter, J. Geophys. Res., 107, 8262, doi:10.1029/2001JD000476, 2002.

Hoppel, K., Bevilacqua, R., Canty, T., Salawitch, R., and Santee, M.: A measurement/model comparion of ozone photochemical loss in the Antarctic ozone hole using Polar Ozone and Aersol Measurement observations and the Match technique, J. Geophys. Res., 110, D19304, doi:10.1029/2004JD005651, 2005.

Inai, Y., Hasebe, F., Fujiwara, M., Shiotani, M., Nishi, N., Ogino, S.Y., Vömel, H., Iwasaki, S., and Shibata, T.: Dehydration in the tropical tropopause layer estimated from the water vapor match, Atmos. Chem. Phys., 13, 8623-8642, doi:10.5194/acp-13-86232013, 2013.

Jackson, D. R. and Orsolini, Y. J.: Estimation of Arctic ozone loss in winter 2004/05 based on assimilation of EOS MLS and SBUV/2 observations, Q. J. Roy. Meteor. Soc., 134, 1833-1841, doi:10.1002/qj.316, 2008.

Jiang, Y. B., Froidevaux, L., Lambert, A., Livesey, N. J., Read, W. G., Waters, J. W., Bojkov, B., Leblanc, T., McDermid, I. S., Godin-Beekmann, S., Filipiak, M. J., Harwood, R. S., Fuller, R. A., Daffer, W. H., Drouin, B. J., Cofield, R. E., Cuddy, D. T., Jarnot, R. F., Knosp, B. W., Perun, V. S., Schwartz, M. J., Snyder, W. V., Stek, P. C., Thurstans, R. P., Wagner, P. A., Allaart, M., Andersen, S. B., Bodeker, G., Calpini, B., Claude, H., Coetzee, G., Davies, J., De Backer, H., Dier, H., Fujiwara, M., Johnson, B., Kelder, H., Leme, N. P., KoenigLanglo, G., Kyro, E., Laneve, G., Fook, L. S., Merrill, J., Morris, G., Newchurch, M., Oltmans, S., Parrondos, M. C., Posny, F., Schmidlin, F., Skrivankova, P., Stubi, R., Tarasick, D., Thompson, A., Thouret, V., Viatte, P., Vomel, H., von Der Gathen, P., Yela, M., and Zablocki, G.: Validation of the Aura Microwave Limb Sounder Ozone by ozonesonde and lidar measurements, J. Geophys. Res., 112, D24S34, doi:10.1029/2007JD008776, 2007.

Jin, J. J., Semeniuk, K., Manney, G. L., Jonsson, A. I., Beagley, S. R., McConnell, J. C., Dufour, G., Nassar, R., Boone, C. D., Walker, K. A., Bernath, P. F., and Rinsland, C. P.: Severe Arctic ozone loss in the winter 2004/2005: observations from ACE-FTS, Geophys. Res. Lett., 33, L15801, doi:10.1029/2006GL026752, 2006.

Knox, J. A.: On converting potential temperature to altitude in the middle atmosphere, EOS, 79, 376-378, 1998.

Kuttippurath, J., Godin-Beekmann, S., Lefèvre, F., and Goutail, F.: Spatial, temporal, and vertical variability of polar stratospheric ozone loss in the Arctic winters 2004/2005-2009/2010, Atmos. Chem. Phys., 10, 9915-9930, doi:10.5194/acp-10-9915-2010, 2010.

Kuttippurath, J., Godin-Beekmann, S., Lefèvre, F., Nikulin, G., Santee, M. L., and Froidevaux, L.: Record-breaking ozone loss in the Arctic winter 2010/2011: comparison with 1996/1997, Atmos. Chem. Phys., 12, 7073-7085, doi:10.5194/acp-12-70732012, 2012.

Lambert, A., Read, W. G., Livesey, N. J., Santee, M. L., Manney, G. L., Froidevaux, L., Wu, D. L., Schwartz, M. J., Pumphrey, H. C., Jimenez, C., Nedoluha, G. E., Cofield, R. E., Cuddy, D. T., Daffer, W. H., Drouin, B. J., Fuller, R. A., Jarnot, R. F., Knosp, B. W., Pickett, H. M., Perun, V. S., Snyder, W. V., Stek, P. C., Thurstans, R. P., Wagner, P. A., Waters, J. W., Jucks, K. W., Toon, G. C., Stachnik, R. A., Bernath, P. F., Boone, C. D., Walker, K. A., Urban, J., Murtagh, D., Elkins, J. W., and Atlas, E.: Validation of the
Aura Microwave Limb Sounder stratospheric water vapor and nitrous oxide measurements, J. Geophys. Res., 112, D24S36, doi:10.1029/2007JD008724, 2007.

Lambert, A., Santee, M. L., Wu, D. L., and Chae, J. H.: A-train CALIOP and MLS observations of early winter Antarctic polar stratospheric clouds and nitric acid in 2008, Atmos. Chem. Phys., 12, 2899-2931, doi:10.5194/acp-12-2899-2012, 2012.

Lehmann, R., von der Gathen, P., Rex, M., and Streibel, M.: Statistical analysis of the precision of the Match method, Atmos. Chem. Phys., 5, 2713-2727, doi:10.5194/acp-5-2713-2005, 2005.

Livesey, N. J., Snyder, W. V., Read, W. G., and Wagner, P. A.: Retrieval algorithms for the EOS Microwave Limb Sounder (MLS), IEEE T. Geosci. Remote, 44, 1144-1155, doi:10.1109/TGRS.2006.872327, 2006.

Livesey, N. J., Filipiak, M. J., Froidevaux, L., Read, W. G., Lambert, A., Santee, M. L., Jiang, J. H., Waters, J. W., Cofield, R. E., Cuddy, D. T., Daffer, W. H., Drouin, B. J., Fuller, R. A., Jarnot, R. F., Jiang, Y. B., Knosp, B. W., Li, Q. B., Perun, V. S., Schwartz, M. J., Snyder, W. V., Stek, P. C., Thurstans, R. P., Wagner, P. A., Pumphrey, H. C., Avery, M., Browell, E. V., Cammas, J.-P., Christensen, L. E., Edwards, D. P., Emmons, L. K., Gao, R.-S., Jost, H.-J., Loewenstein, M., Lopez, J. D., Nédélec, P., Osterman, G. B., Sachse, G. W., and Webster, C. R.: Validation of Aura Microwave Limb Sounder $\mathrm{O}_{3}$ and $\mathrm{CO}$ observations in the upper troposphere and lower stratosphere, J. Geophys. Res., 113, D15S02, doi:10.1029/2007JD008805, 2008.

Livesey, N. J., Read, W. G., Froidevaux, L., Lambert, A., Manney, G. L., Pumphrey, H. C., Santee, M. L., Schwartz, M. J., Wang, S., Cofield, R. E., Cuddy, D. T., Fuller, R. A., Jarnot, R. F., Jiang, J. H., Knosp, B. W., Stek, P. C., Wagner, P. A., and Wu, D. L.: EOS MLS Version 3.3 and 3.4 Level 2 data quality and description document, Tech. rep., Jet Propulsion Laboratory, California Institute of Technology, available at: http: //mls.jpl.nasa.gov/ (last access: 27 March 2015), 2013.

Manney, G. L., Zurek, R. W., O’Neill, A., and Swinbank, R.: On the motion of air through the stratospheric polar vortex, J. Atmos. Sci., 51, 2973-2994, 1994.

Manney, G. L., Zurek, R. W., Froidevaux, L., Waters, J. W., O'Neill, A., and Swinbank, R.: Lagrangian transport calculations using UARS Data, Part II: Ozone, J. Atmos. Sci., 52, 3069-3081, 1995a.

Manney, G. L., Zurek, R. W., Lahoz, W. A., Harwood, R. S., Gille, J. C., Kumer, J. B., Mergenthaler, J. L., Roche, A. E., O'neill, A., Swinbank, R., and Waters, J. W.: Lagrangian transport calculations using UARS Data, Part I: Passive tracers, J. Atmos. Sci., 52, 3049-3068, 1995b.

Manney, G. L., Froidevaux, L., Waters, J. W., Santee, M. L., Read, W. G., Flower, D. A., Jarnot, R. F., and Zurek, R. W.: Arctic ozone depletion observed by UARS MLS during the 1994-95 winter, Geophys. Res. Lett., 23, 85-88, doi:10.1029/95GL03591, 1996a.

Manney, G. L., Santee, M. L., Froidevaux, L., Waters, J. W., and Zurek, R. W.: Polar vortex conditions during the 1995-96 Arctic winter: meteorology and MLS ozone, Geophys. Res. Lett., 23, 3203-3206, doi:10.1029/96GL02453, 1996b.

Manney, G. L., Froidevaux, L., Santee, M. L., Zurek, R. W., and Waters, J. W.: MLS observations of Arctic ozone loss in 1996-97, 
Geophys. Res. Lett., 24, 2697-2700, doi:10.1029/97GL52827, 1997.

Manney, G. L., Froidevaux, L., Santee, M. L., Livesey, N. J., Sabutis, J. L., and Waters, J. W.: Variability of ozone loss during Arctic winter (1991-2000) estimated from UARS Microwave Limb Sounder measurements, J. Geophys. Res., 108, 4149, doi:10.1029/2002JD002634, 2003.

Manney, G. L., Santee, M. L., Froidevaux, L., Hoppel, K., Livesey, N. J., and Waters, J. W.: EOS MLS observations of ozone loss in the 2004-2005 Arctic winter, Geophys. Res. Lett., 33, L04892, doi:10.1029/2005GL024494, 2006.

Manney, G. L., Daffer, W. H., Zawodny, J. M., Bernath, P. F., Hoppel, K. W., Walker, K. A., Knosp, B. W., Boone, C., Remsberg, E. E., Santee, M. L., Harvey, V. L., Pawson, S., Jackson, D. R., Deaver, L., McElroy, C. T., McLinden, C. A., Drummond, J. R., Pumphrey, H. C., Lambert, A., Schwartz, M. J., Froidevaux, L., McLeod, S., Takacs, L. L., Suarez, M. J., Trepte, C. R., Cuddy, D. C., Livesey, N. J., Harwood, R. S., and Waters, J. W.: Solar occultation satellite data and derived meteorological products: Sampling issues and comparisons with Aura Microwave Limb Sounder, J. Geophys. Res., 112, D24S50, doi:10.1029/2007JD008709, 2007.

Manney, G. L., Krüger, K., Pawson, S., Minschwaner, K., Schwartz, M. J., Daffer, W. H., Livesey, N. J., Mlynczak, M. G., Remsberg, E. E., Russel III, J. M., and Waters, J. W.: The evolution of the stratopause during the 2006 major warming: satellite data and assimilated meteorological analyses, J. Geophys. Res., 113, D11115, doi:10.1029/2007JD009097, 2008.

Manney, G. L., Harwood, R. S., MacKenzie, I. A., Minschwaner, K., Allen, D. R., Santee, M. L., Walker, K. A., Hegglin, M. I., Lambert, A., Pumphrey, H. C., Bernath, P. F., Boone, C. D., Schwartz, M. J., Livesey, N. J., Daffer, W. H., and Fuller, R. A.: Satellite observations and modeling of transport in the upper troposphere through the lower mesosphere during the 2006 major stratospheric sudden warming, Atmos. Chem. Phys., 9, 47754795, doi:10.5194/acp-9-4775-2009, 2009.

Manney, G. L., Hegglin, M. I., Daffer, W. H., Santee, M. L., Ray, E. A., Pawson, S., Schwartz, M. J., Boone, C. D., Froidevaux, L., Livesey, N. J., Read, W. G., and Walker, K. A.: Jet characterization in the upper troposphere/lower stratosphere (UTLS): applications to climatology and transport studies, Atmos. Chem. Phys., 11, 6115-6137, doi:10.5194/acp-11-6115-2011, 2011.

Manney, G. L., Lawrence, Z. D., Santee, M. L., Livesey, N. J., Lambert, A., and Pitts, M. C.: Polar processing in a split vortex: Arctic ozone loss in early winter 2012/2013, Atmos. Chem. Phys., 15, 5381-5403, doi:10.5194/acp-15-5381-2015, 2015.

McCormick, M. P., Steele, H. M., Hamill, P., Chu, W. P., and Swissler, T. J.: Polar Stratospheric Cloud sightings by SAM II., J. Atmos. Sci., 39, 1387-1397, 1982.

Methven, J., Arnold, S. R., Stohl, A., Evans, M. J., Avery, M., Law, K., Lewis, A. C., Monks, P. S., Parrish, D. D., Reeves, C. E., Schlager, H., Atlas, E., Blake, D. R., Coe, H., Crosier, J., Flocke, F. M., Holloway, J. S., Hopkins, J. R., McQuaid, J., Purvis, R., Rappenglück, B., Singh, H. B., Watson, N. M., Whalley, L. K., and Williams, P. I.: Establishing Lagrangian connections between observations within air masses crossing the Atlantic during the International Consortium for Atmospheric Research on Transport and Transformation experiment, J. Geophys. Res., 111, D23S62, doi:10.1029/2006JD007540, 2006.
Michelsen, H. A., Manney, G. L., Gunson, M. R., and Zander, R.: Correlations of stratospheric abundances of $\mathrm{NO}_{\mathrm{y}}, \mathrm{O}_{3}, \mathrm{~N}_{2} \mathrm{O}$, and $\mathrm{CH}_{4}$ derived from ATMOS measurements, J. Geophys. Res., 103, 28347-28359, 1998.

Molina, L. T. and Molina, M. J.: Production of $\mathrm{Cl}_{2} \mathrm{O}_{2}$ from the selfreaction of the $\mathrm{ClO}$ radical, J. Phys. Chem., 91, 433-436, 1987.

Morris, G. A., Gleason, J. F., Russell III, J. M., Schoeberl, M. R., and McCormick, M. P.: A comparison of HALOE V19 with SAGE II V6.00 ozone observations using trajectory mapping, J. Geophys. Res., 107, 4177, doi:10.1029/2001JD000847, 2002.

Müller, R., Tilmes, S., Konopka, P., Grooß, J.-U., and Jost, H.J.: Impact of mixing and chemical change on ozone-tracer relations in the polar vortex, Atmos. Chem. Phys., 5, 3139-3151, doi:10.5194/acp-5-3139-2005, 2005.

Papanastasiou, D. K., Papadimitriou, V. C., Fahey, D. W., and Burkholder, J. B.: UV absorption spectrum of the $\mathrm{ClO}$ dimer $\left(\mathrm{Cl}_{2} \mathrm{O}_{2}\right)$ between 200 and $420 \mathrm{~nm}$, J. Phys. Chem. A, 113, 13711-13726, doi:10.1021/jp9065345, 2009.

Pfister, L., Selkirk, H. B., Jensen, E. J., Schoeberl, M. R., Toon, O. B., Browell, E. V., Grant, W. B., Gary, B., Mahoney, M. J., Bui, T. V., and Hintsa, E.: Aircraft observations of thin cirrus clouds near the tropical tropopause, J. Geophys. Res., 106, 9765-9786, doi:10.1029/2000JD900648, 2001.

Pfister, L., Selkirk, H. B., Starr, D. O., Newman, P. A., and Rosenlof, K. H.: A meteorological overview of the TC4 mission, J. Geophys. Res., 115, D00J12, doi:10.1029/2009JD013316, 2010.

Plumb, R. A.: Tracer interrelationships in the stratosphere, Rev. Geophys., 45, RG4005, doi:10.1029/2005RG000179, 2007.

Plumb, R. A., Waugh, D. W., and Chipperfield, M. P.: The effects of mixing on tracer relationships in the polar vortices, J. Geophys. Res., 105, 10047-10062, doi:10.1029/1999JD901023, 2000.

Pope, F. D., Hansen, J. C., Bayes, K. D., Friedl, R. R., and Sander, S. P.: Ultraviolet absorption spectrum of chlorine perocide, $\mathrm{ClOOCl}$, J. Phys. Chem., 111, 4322-4332, doi:10.1021/jp067660w, 2007.

Proffitt, M. H., Aikin, K., Margitan, J. J., Loewenstein, M., Podolske, J. R., Weaver, A., Chan, K. R., Fast, H., and Elkins, J. W.: Ozone loss inside the northern polar vortex during the 1991-1992 winter, Science, 261, 1150-1154, 1993.

Rex, M., Harris, N. R. P., von der Gathen, P., Lehmann, R., Braathen, G. O., Reimer, E., Beck, A., Chipperfield, M. P., Alfier, R., Allaart, M., O'Connor, F., Dier, H., Dorokhov, V., Fast, H., Gil, M., Kyrö, E., Litynska, Z., Mikkelsen, I. S., Molyneux, M. G., Nakane, H., Notholt, J., Rummukainen, M., Viatte, P., and Wenger, J.: Prolonged stratospheric ozone loss in the 1995-96 Arctic winter, Nature, 389, 835-838, doi:10.1038/39849, 1997.

Rex, M., von der Gathen, P., Harris, N. R. P., Lucic, D., Knudsen, B. M., Brathen, G. O., Reid, S. J., Backer, H. D., Claude, H., Fabian, R., Fast, H., Gil, M., Kyrö, E., Mikkelsen, I. S., Rummukainen, M., Smit, H. G., Stähelin, J., Varotsos, C., and Zaitcev, I.: In situ measurements of stratospheric ozone depletion rates in the Arctic winter 1991/1992: a Lagrangian approach, J. Geophys. Res., 103, 5843-5853, 1998.

Rex, M., von der Gathen, P., Braathen, G. O., Harris, N. R. P., Reimer, E., Beck, A., Alfier, R., Krüger-carstensen, R., Chipperfield, M., de Backer, H., Balis, D., O'Connor, F., Dier, H., Dorokhov, V., Fast, H., Gamma, A., Gil, M., Kyro, E., Lityn- 
ska, Z., Mikkelsen, I. S., Molyneux, M., Murphy, G., Reid, S. J., Rummukainen, M., and Zerefos, C.: Chemical ozone loss in the Arctic winter 1994/95 as determined by the Match technique, J. Atmos. Chem., 32, 35-59, doi:10.1023/A:1006093826861, 1999.

Rex, M., Salawitch, R. J., Deckelmann, H., von der Gathen, P., Harris, N. R. P., Chipperfield, M. P., Naujokat, B., Reimer, E., Allaart, M., Andersen, S. B., Bevilacqua, R., Braathen, G. O., Claude, H., Davies, J., de Backer, H., Dier, H., Dorokhov, V., Fast, H., Gerding, M., Godin-Beekmann, S., Hoppel, K., Johnson, B., Kyro, E., Litynska, Z., Moore, D., Nakane, H., Parrondo, M. C., Risley, Jr., A. D., Skrivankova, P., Stubi, R., Viatte, P., Yushkov, V., and Zerefos, C.: Arctic winter 2005: implications for stratospheric ozone loss and climate change, Geophys. Res. Lett., 33, L23808, doi:10.1029/2006GL026731, 2006.

Rienecker, M. M., Suarez, M. J., Todling, R., Bacmeister, K., Takacs, L., Liu, H.-C., Gu, W., Sienkiewicz, M., Koster, R. D., Gelaro, R., Stajner, I., and Nielsen, J. E.: The GEOS-5 Data Assimilation System - Documentation of Versions 5.0.1, 5.1.0, and 5.2.0, Tech. rep., NASA Goddard Space Flight Center, Greenbelt, MD., NASA/TM-2008-10406, Vol. 27, 2008.

Rivière, E. D., Terao, Y., and Nakajima, H.: A Lagrangian method to study stratospheric nitric acid variations in the polar regions as measured by the Improved Limb Atmospheric Spectrometer, J. Geophys. Res., 108, 4718, doi:10.1029/2003JD003718, 2003.

Rösevall, J. D., Murtagh, D. P., Urban, J., Feng, W., Eriksson, P., and Brohede, S.: A study of ozone depletion in the 2004/2005 Arctic winter based on data from Odin/SMR and Aura/MLS, J. Geophys. Res., 113, D13301, doi:10.1029/2007JD009560, 2008.

Santee, M. L., Tabazadeh, A., Manney, G. L., Fromm, M. D., Bevilacqua, R. M., Waters, J. W., and Jensen, E. J.: A Lagrangian approach to studying Arctic polar stratospheric clouds using UARS MLS $\mathrm{HNO}_{3}$ and POAM II aerosol extinction measurements, J. Geophys. Res., 107, 4098, doi:10.1029/2000JD000227, 2002.

Santee, M. L., Manney, G. L., Waters, J. W., and Livesey, N. J.: Variations and climatology of $\mathrm{ClO}$ in the polar lower stratosphere from UARS MLS measurements, J. Geophys. Res., 108, 4454, doi:10.1029/2002JD003335, 2003.

Santee, M. L., MacKenzie, I. A., Manney, G. L., Chipperfield, M. P., Bernath, P. F., Walker, K. A., Boone, C. D., Froidevaux, L., Livesey, N. J., and Waters, J. W.: A study of stratospheric chlorine partitioning based on new satellite measurements and modeling, J. Geophys. Res., 113, D12307, doi:10.1029/2007JD009057, 2008.

Santee, M. L., Manney, G. L., Livesey, N. J., Froidevaux, L., Schwartz, M. J., and Read, W. G.: Trace gas evolution in the lowermost stratosphere from Aura Microwave Limb Sounder measurements, J. Geophys. Res., 116, D18306, doi:10.1029/2011JD015590, 2011.

Sasano, Y., Terao, Y., Tanaka, H. L., Yasunari, T., Kanzawa, H., Nakajima, H., Yokota, T., Nakane, H., Hayashida, S., and Saitoh, N.: ILAS observations of chemical ozone loss in the Arctic vortex during early spring 1997, Geophys. Res. Lett., 27, 213 216, 2000

Sayres, D. S., Pfister, L., Hanisco, T. F., Moyer, E. J., Smith, J. B., St Clair, J. M., O’Brien, A. S., Witinski, M. F., Legg, M., and Anderson, J. G.: Influence of convection on the water isotopic composition of the tropical tropopause layer and tropical stratosphere, J. Geophys. Res., 115, D00J20, doi:10.1029/2009JD013100, 2010.

Schoeberl, M. R., Lait, L. R., Newman, P. A., and Rosenfield, J. E.: The Structure of the polar vortex, J. Geophys. Res., 97, 78597882, 1992.

Schoeberl, M. R., Newman, P. A., Lait, L. R., McGee, T. J., Burris, J. F., Browell, E. V., Grant, W. B., Richard, E. C., von der Grathen, P., Bevilacqua, R., and Mikkelsen, I. S.: An assessment of the ozone loss during the 1999-2000 SOLVE/THESEO 2000 Arctic campaign, J. Geophys. Res., 107, 8261, doi:10.1029/2001JD000412, 2002.

Schoeberl, M. R., Ziemke, J. R., Bojkov, B., Livesey, N., Duncan, B., Strahan, S., Froidevaux, L., Kulawik, S., Bhartia, P. K., Chandra, S., Levelt, P. F., Witte, J. C., Thompson, A. M., Cuevas, E., Redondas, A., Tarasick, D. W., Davies, J., Bodeker, G., Hansen, G., Johnson, B. J., Oltmans, S. J., Vömel, H., Allaart, M., Kelder, H., Newchurch, M., GodinBeekmann, S., Ancellet, G., Claude, H., Kyrö, S. B. A. E., Parrondos, M., Yela, M., Zablocki, G., Moore, D., Dier, H., von der Gathen, P., Stübi, P. V. R., Calpini, B., Dorokhov, P. S. V., de Backer, H., Schmidlin, F. J., Coetzee, G., Fujiwara, M., Thouret, V., Posny, F., Morris, G., Merrill, J., Leong, C. P., Koenig-Langlo, G., and Joseph, E.: A trajectory-based estimate of the tropospheric ozone column using the residual method, J. Geophys. Res., 112, D24S49, doi:10.1029/2007JD008773, 2007.

Schofield, R., Frieler, K., Wohltmann, I., Rex, M., von Hobe, M., Stroh, F., Koch, G., Peter, T., Canty, T., Salawitch, R., and Volk, C. M.: Polar stratospheric chlorine kinetics from a selfmatch flight during SOLVE-II/EUPLEX, Geophys. Res. Lett., 35, L01807, doi:10.1029/2007GL031740, 2008.

Schofield, R., Avallone, L. M., Kalnajs, L. E., Hertzog, A., Wohltmann, I., and Rex, M.: First quasi-Lagrangian in situ measurements of Antarctic Polar springtime ozone: observed ozone loss rates from the Concordiasi long-duration balloon campaign, Atmos. Chem. Phys., 15, 2463-2472, doi:10.5194/acp-15-24632015, 2015.

Singleton, C. S., Randall, C. E., Chipperfield, M. P., Davies, S., Feng, W., Bevilacqua, R. M., Hoppel, K. W., Fromm, M. D., Manney, G. L., and Harvey, V. L.: 2002-2003 Arctic ozone loss deduced from POAM III satellite observations and the SLIMCAT chemical transport model, Atmos. Chem. Phys., 5, 597609, doi:10.5194/acp-5-597-2005, 2005.

Singleton, C. S., Randall, C. E., Harvey, V. L., Chipperfield, M. P., Feng, W., Manney, G. L., Froidevaux, L., Boone, C. D., Bernath, P. F., Walker, K. A., McElroy, C. T., and Hoppel, K. W.: Quantifying ozone loss during the 2004/2005 Arctic winter, J. Geophys. Res., 112, D07304, doi:10.1029/2006JD007463, 2007.

Sinnhuber, B. M., Stiller, G., Ruhnke, R., von Clarmann, T., Kellmann, S., and Aschmann, J.: Arctic winter 2010/2011 at the brink of an ozone hole, Geophys. Res. Lett., 38, L24814, doi:10.1029/2011GL049784, 2011.

Solomon, S.: Stratospheric ozone depletion: a review of concepts and history, Rev. Geophys., 37, 275-316, 1999.

Solomon, S., Garcia, R. R., Rowland, F. S., and Wuebbles, D. J.: On the depletion of Antarctic ozone, Nature, 321, 755, 1986.

Sumińska-Ebersoldt, O., Lehmann, R., Wegner, T., Grooß, J.-U., Hösen, E., Weigel, R., Frey, W., Griessbach, S., Mitev, V., Emde, C., Volk, C. M., Borrmann, S., Rex, M., Stroh, F., and von Hobe, $\mathrm{M}$.: $\mathrm{ClOOCl}$ photolysis at high solar zenith angles: analysis of the 
RECONCILE self-match flight, Atmos. Chem. Phys., 12, 13531365, doi:10.5194/acp-12-1353-2012, 2012.

Terao, Y., Sasano, Y., Nakajima, H., Tanaka, H. L., and Yasunari, T.: Stratospheric ozone loss in the 1996/1997 Arctic winter: evaluation based on multiple trajectory analysis for doublesounded air parcels by ILAS, J. Geophys. Res., 107, 8210, doi:10.1029/2001JD000615, 2002.

Terao, Y., Sugita, T., and Sasano, Y.: Ozone loss rates in the Arctic winter stratosphere during 1994-2000 derived from POAM II/III and ILAS observations: implications for relationships among ozone loss, PSC occurrence, and temperature, J. Geophys. Res., 117, D05311, doi:10.1029/2011JD016789, 2012.

Toon, O. B., Hamill, P., Turco, R. P., and Pinto, J.: Condensation of $\mathrm{HNO}_{3}$ and $\mathrm{HCl}$ in the Winter Polar Stratospheres, Geophys. Res. Lett., 13, 1284-1287, 1986.

Toon, O. B., Browell, E. V., Kinne, S., and Jordan, J.: An analysis of lidar observations of Polar Stratospheric Clouds, Geophys. Res. Lett., 17, 393-396, 1990.

Tsvetkova, N. D., Yushkov, V. A., Luk'yanov, A. N., Dorokhov, V. M., and Nakane, H.: Record-breaking chemical destruction of ozone in the Arctic during the winter of 2004/2005, Izvestiya, 43, 592-598, doi:10.1134/S0001433807050076, 2007.

von Clarmann, T., Höpfner, M., Kellmann, S., Linden, A., Chauhan, S., Funke, B., Grabowski, U., Glatthor, N., Kiefer, M., Schieferdecker, T., Stiller, G. P., and Versick, S.: Retrieval of temperature, $\mathrm{H}_{2} \mathrm{O}, \mathrm{O}_{3}, \mathrm{HNO}_{3}, \mathrm{CH}_{4}, \mathrm{~N}_{2} \mathrm{O}, \mathrm{ClONO}_{2}$ and $\mathrm{ClO}$ from MIPAS reduced resolution nominal mode limb emission measurements, Atmos. Meas. Tech., 2, 159-175, doi:10.5194/amt-2-159-2009, 2009.

von der Gathen, P., Rex, M., Harris, N. R. P., Lucic, D., Knudsen, B. M., Braathen, G. O., de Backer, H., Fabian, R., Fast, H., Gil, M., Kyrö, E., Mikkelsen, I. S., Rummukainen, M., Stähelin, J., and Varotsos, C.: Observational evidence for chemical ozone depletion over the Arctic in winter 1991-92, Nature, 375, 131-134, 1995.

von Hobe, M., Ulanovsky, A., Volk, C. M., Grooß, J. U., Tilmes, S., Konopka, P., Günther, G., Werner, A., Spelten, N., Shur, G., Yushkov, V., Ravegnani, F., Schiller, C., Müller, R., and Stroh, F.: Severe ozone depletion in the cold Arctic winter 2004-05, Geophys. Res. Lett., 33, L17815, doi:10.1029/2006GL026945, 2006. von Hobe, M., Salawitch, R. J., Canty, T., Keller-Rudek, H., Moortgat, G. K., Grooß, J.-U., Müller, R., and Stroh, F.: Understanding the kinetics of the $\mathrm{ClO}$ dimer cycle, Atmos. Chem. Phys., 7, 3055-3069, doi:10.5194/acp-7-3055-2007, 2007.

Waters, J. W., Froidevaux, L., Harwood, R. S., Jarnot, R. F., Pickett, H. M., Read, W. G., Siegel, P. H., Cofield, R. E., Filipiak, M. J., Flower, D. A., Holden, J. R., Lau, G. K., Livesey, N. J., Manney, G. L., Pumphrey, H. C., Santee, M. L., Wu, D. L., Cuddy, D. T., Lay, R. R., Loo, M. S., Perun., V. S., Schwartz, M. J., Stek, P. C., Thurstans, R. P., Chandra, K. M., Chavez, M. C., Chen, G., Boyles, M. A., Chudasama, B. V., Dodge, R., Fuller, R. A., Girard, M. A., Jiang, J. H., Jiang, Y., Knosp, B. W., LaBelle, R. C., Lam, J. C., Lee, K. A., Miller, D., Oswald, J. E., Patel, N. C., Pukala, D. M., Quintero, O., Scaff, D. M., Snyder, W. V., Tope, M. C., Wagner, P. A., and Walch, M. J.: The Earth Observing System Microwave Limb Sounder (EOS MLS) on the Aura satellite, IEEE T. Geosci. Remote, 44, 1075-1092, 2006.

Waugh, D. W., Plumb, R. A., Elkins, J. W., Fahey, D. W., Boering, K. A., Dutton, G. S., Volk, C. M., Keim, E., Gao, R.-S., Daube, B. C., Wofsy, S. C., Loewenstein, M., Podolske, J. R., Chan, K. R., Proffitt, M. H., Kelly, K. K., Newman, P. A., and Lait, L. R.: Mixing of polar vortex air into middle latitudes as revealed by tracer-tracer scatterplots, J. Geophys. Res., 102, 13119-13134, 1997.

World Meteorological Organization: Scientific Assessment of Ozone Depletion: 2006, Tech. rep., World Meteorological Organization, Global Ozone Research and Monitoring Project - Report No. 50, Geneva, Switzerland, 2007.

World Meteorological Organization: Scientific Assessment of Ozone Depletion: 2014, Tech. rep., World Meteorological Organization, Global Ozone Research and Monitoring Project - Report No. 55, Geneva, Switzerland, 2014. 